\title{
Photochemical Dihydrogen Production using an Analogue of the Active site of [NiFe] Hydrogenase
}

Peter A. Summers, Joe Dawson, Fabio Ghiotto, Magnus W. D. Hanson-Heine, Khuong Q.

Vuong, E. Stephen Davies, Xue-Z. Sun, Nicholas A. Besley, Jonathan McMaster,* Michael W. George* and Martin Schröder*

School of Chemistry, University of Nottingham, Nottingham, NG7 2RD, UK

\section{Email:}

M.Schroder@nottingham.ac.uk; J.McMaster@nottingham.ac.uk;

Mike.George@nottingham.ac.uk 


\begin{abstract}
The photoproduction of dihydrogen $\left(\mathrm{H}_{2}\right)$ by a low molecular weight analogue of the active site of [NiFe] hydrogenase has been investigated by the reduction of the $\left[\mathrm{NiFe}_{2}\right]$ cluster, $\mathbf{1}$, by a photosensitier PS $\left(\mathrm{PS}=\left[\operatorname{ReCl}(\mathrm{CO})_{3}(\mathrm{bpy})\right]\right.$ or $\left.\left[\mathrm{Ru}(\mathrm{bpy})_{3}\right]\left[\mathrm{PF}_{6}\right]_{2}\right)$. Reductive quenching of the ${ }^{3}$ MLCT excited state of the photosensitiser by $\mathrm{NEt}_{3}$ or $\mathrm{N}\left(\mathrm{CH}_{2} \mathrm{CH}_{2} \mathrm{OH}\right)_{3}$ (TEOA) generates PS ${ }^{\circ}$, and subsequent intermolecular electron transfer to $\mathbf{1}$ produces the reduced anionic form of $\mathbf{1}$. Time-resolved infrared spectroscopy (TRIR) has been used to probe the intermediates throughout the reduction of $\mathbf{1}$ and subsequent photocatalytic $\mathrm{H}_{2}$ production from [HTEOA] $\left[\mathrm{BF}_{4}\right]$, which was monitored by gas chromatography. Two structural isomers of the reduced form of $\mathbf{1}\left(\mathbf{1 a}^{\mathbf{*}}\right.$ and $\mathbf{1 b}^{\mathbf{0}^{-}}$) were detected by Fourier transform infrared spectroscopy (FTIR) in both $\mathrm{CH}_{3} \mathrm{CN}$ and DMF (dimethylformamide), while only $\mathbf{1 a}^{--}$was detected in $\mathrm{CH}_{2} \mathrm{Cl}_{2}$. Structures for these intermediates are proposed from the results of density functional theory calculations and FTIR spectroscopy. $\mathbf{1 a}^{--}$is assigned to a similar structure to $\mathbf{1}$ with six terminal carbonyl ligands, while calculations suggest that in $\mathbf{1 b}^{\mathbf{0}^{-}}$two of the carbonyl groups bridge the Fe centres, consistent with the peak observed at $1714 \mathrm{~cm}^{-1}$ in the FTIR spectrum for $\mathbf{1 b}^{--}$in $\mathrm{CH}_{3} \mathrm{CN}$, assigned to a $v(\mathrm{CO})$ stretching vibration. The formation of $\mathbf{1 a}^{--}$and $\mathbf{1 \mathbf { b } ^ { - - }}$ and the production of $\mathrm{H}_{2}$ was studied in $\mathrm{CH}_{3} \mathrm{CN}$, DMF and $\mathrm{CH}_{2} \mathrm{Cl}_{2}$. Although the more catalytically active species $\left(\mathbf{1 a}^{--}\right.$or $\left.\mathbf{1 b}^{-}\right)$could not be determined, photocatalysis was observed only in $\mathrm{CH}_{3} \mathrm{CN}$ and DMF.
\end{abstract}

Keywords: Hydrogenase, rhenium, nickel, iron, thiolate, time-resolved IR, proton reduction 


\section{Introduction}

The development of efficient catalysts for the light-driven production of dihydrogen $\left(\mathrm{H}_{2}\right)$ is a significant challenge in the development of the hydrogen economy, ${ }^{1}$ and much attention has focused on the development of efficient catalysts for the light-induced splitting of $\mathrm{H}_{2} \mathrm{O}$ into $\mathrm{H}_{2}$ and $\mathrm{O}_{2}{ }^{2}$ The conversion of $\mathrm{H}_{2} \mathrm{O}$ to $\mathrm{H}_{2}$ using solar energy can be a complex, multi-step and multielectron process involving charge separation and bond breaking and formation. ${ }^{3}$ Systems containing light absorbing units, electron relays and redox catalysts have been targeted to overcome these chemical challenges, and have led to the development of the three component system. ${ }^{4}$ Traditionally, these systems consist of a photosensitiser, an electron mediator (usually methyl viologen $\left[\mathrm{MV}^{2+}\right]$ ) and a homogeneous or heterogeneous metal, that catalyses the reduction of protons to $\mathrm{H}_{2}$. In addition, a sacrificial electron donor, such as an amine that may be oxidised readily, injects electrons into the system to complete the catalytic cycle. In recent years, efforts have progressed towards the development of a range of homogeneous catalysts, containing $\mathrm{Co}, \mathrm{Pt}, \mathrm{Pd}, \mathrm{Rh}, \mathrm{Fe}$ and $\mathrm{Ni}^{2 \mathrm{a}, 2 \mathrm{c}, 2 \mathrm{~d}}$ centres where the reaction mechanism of proton reduction may be investigated more readily than in heterogeneous catalysts.

The nature of the active sites of the $[\mathrm{NiFe}]$ and $[\mathrm{FeFe}]$ hydrogenases ${ }^{5}$ have inspired the synthesis of low molecular weight complexes that replicate the structural, spectroscopic, and functional aspects of these centres, ${ }^{6}$ and that may act as in vitro catalysts for $\mathrm{H}_{2}$ production. While the majority of these compounds have focused on the replication of the features of the active sites of the $[\mathrm{FeFe}]$ hydrogenases, ${ }^{7}$ we have focused our attention on the preparation of analogues of the active sites of the $[\mathrm{NiFe}]$ hydrogenases $($ Scheme 1$) ;^{8}$ the $[\mathrm{NiFe}]$ hydrogenases are $10-10^{2}$ times less active towards $\mathrm{H}_{2}$ production, but show a higher affinity for $\mathrm{H}_{2}$, and are less sensitive to dioxygen and to deactivation by carbon monoxide when compared to their [FeFe] counterparts. ${ }^{7-9}$ We have reported previously an electrocatalytically-active heteronuclear $\left[\mathrm{NiFe}_{2}\right]$ cluster as an analogue of the active site of the $[\mathrm{NiFe}]$ hydrogenases $(\mathbf{1}$, Scheme 1$) .{ }^{10}$ Upon electrochemical 
reduction of $\mathbf{1}$ to $\mathbf{1}^{--}$in acidic media, catalytic production of $\mathrm{H}_{2}$ in homogeneous solution occurs with a turn-over frequency (TOF) estimated at $c a .6 \mathrm{~h}^{-1}$ at a potential of $-1.31 \mathrm{~V} v s \mathrm{Fc}^{+} / \mathrm{Fc}$ in $\mathrm{CH}_{2} \mathrm{Cl}_{2}{ }^{11}$ The catalytic activity of $\mathbf{1}^{--}$is comparable to those of first-generation analogues of the active site of the $[\mathrm{FeFe}]$ hydrogenases but at a potential that is considerably more positive. ${ }^{12}$

(a)

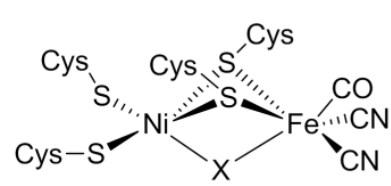

(b)

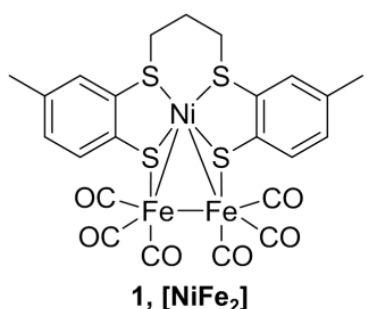

(c)

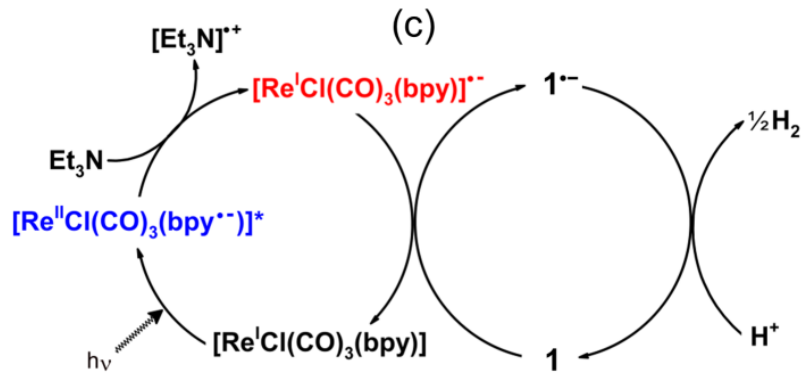

Scheme 1. (a) Schematic representation of the inactive form of the $[\mathrm{NiFe}]$ hydrogenase $(X=$ $\mathrm{HOO}^{-}$for $\mathrm{Ni}-\mathrm{A}$ and $\mathrm{HO}^{-}$for $\left.\mathrm{Ni}-\mathrm{B}\right){ }^{7 \mathrm{a}}$ (b) $\mathbf{1}\left(\left[\mathrm{Ni}(\mathrm{L}) \mathrm{Fe}_{2}(\mathrm{CO})_{6}\right], \mathrm{L}^{2-}=\left(\mathrm{CH}_{3} \mathrm{C}_{6} \mathrm{H}_{3} \mathrm{~S}_{2}\right)_{2}\left(\mathrm{CH}_{2}\right)_{3}\right)^{10}$ and (c) a proposed mechanism for the light-driven electron transfer to 1 using $\left[\operatorname{ReCl}(\mathrm{CO})_{3}(\right.$ bpy) $]$ as a photosensitiser and $\mathrm{NEt}_{3}$ as a sacrificial electron donor.

Intermolecular electron transfer to analogues of the active sites of the [FeFe] hydrogenases, $\left[\mathrm{Fe}_{2}(\mathrm{CO})_{4} \mathrm{X}\left(\mathrm{L}^{1}\right)\left(\mathrm{L}^{2}\right)\right]$, from photogenerated $\left[\mathrm{Ru}(\mathrm{bpy})_{3}\right]^{+}$has been investigated using diethyldithiocarbamate $\left(\mathrm{dtc}^{-}\right)$as an electron donor (for $\mathrm{X}=\left(\mu-\mathrm{SCH}_{2}\right)_{2} \mathrm{CH}_{2}$ or $(\mu$ $\left.\left.\mathrm{SCH}_{2}\right)_{2} \mathrm{NCH}_{2} \mathrm{C}_{6} \mathrm{H}_{5}, \mathrm{~L}^{1}=\mathrm{L}^{2}=\mathrm{CO}\right)^{13}$ and the evolution of $\mathrm{H}_{2}$ occurs when ascorbic acid is used as both electron donor and proton source (for $\mathrm{X}=\left(\mu-\mathrm{SCH}_{2}\right)_{2} \mathrm{NCH}_{2} \mathrm{C}_{6} \mathrm{H}_{5}, \mathrm{~L}^{1}=\mathrm{L}^{2}=$ $\mathrm{P}(\mathrm{Pyr})_{3}$ or $\mathrm{L}^{1}=\mathrm{CO} \mathrm{L}^{2}=\mathrm{P}(\mathrm{Pyr})_{3}, \mathrm{Pyr}=N$-pyrrolyl $) .{ }^{14}$ Switching to $\mathrm{NEt}_{3}$ as the electron donor and cyclometallated iridium(II) as the photosensitiser, leads to a turn-over number (TON) of 
466 in this system. ${ }^{15}$ Ascorbic acid has also been employed as the electron donor and proton source with $\left[\mathrm{Ru}(\mathrm{bpy})_{3}\right]^{2+}$ as the photosensitiser in a catalytic system (for $\mathrm{X}=\mu-\mathrm{Cl}_{2} \mathrm{bdt}, \mathrm{L}^{1}=$ $\mathrm{L}^{2}=\mathrm{CO}, \mathrm{Cl}_{2}$ bdt $=3$,6-dichlorobenzene-1,2-dithiolate) that exhibits a TON of $200 .{ }^{16}$ Water soluble $\left[\mathrm{Fe}_{2}(\mathrm{CO})_{4} \mathrm{X}\left(\mathrm{L}^{1}\right)\left(\mathrm{L}^{2}\right)\right]\left(\mathrm{X}=\left(\mu-\mathrm{SCH}_{2}\right)_{2} \mathrm{CH}_{2}, \mathrm{~L}^{1}=\mathrm{CO}, \mathrm{L}^{2}=\right.$ a functionalized isonitrile $)$ is catalytically active $(\mathrm{TON}=505)$ when $\mathrm{CdTe}$ quantum dots are employed as the photosensitiser and ascorbic acid as a combined electron and proton source. ${ }^{17}$ In addition, photocatalytic $\mathrm{H}_{2}$ evolution occurs for $\left[\mathrm{Fe}_{2}(\mathrm{CO})_{6}(\mu\right.$-adt $\left.) \mathrm{CH}_{2} \mathrm{C}_{6} \mathrm{H}_{5}\right]$ or $\left[\mathrm{Fe}_{2}(\mathrm{CO})_{6}(\mu\right.$-adt $\left.) \mathrm{C}_{6} \mathrm{H}_{5}\right]$ $\left[\mu\right.$-adt $\left.=\mathrm{N}\left(\mathrm{CH}_{2} \mathrm{~S}\right)_{2}\right]$ encapsulated in a dodecyl sulfate micelle in water with $\left[\operatorname{ReBr}(\mathrm{CO})_{3}(4,4-\right.$ dimethylbpy)] and $\left[\operatorname{ReBr}(\mathrm{CO})_{3}(1,10\right.$-phenanthroline $\left.)\right]$ as photosensitisers. However, the TON is low for these systems $(\mathrm{TON} \leq 0.13) .{ }^{18} \mathrm{Ni}$-only catalysts that have been incorporated into $\mathrm{H}_{2}$-evolving systems can demonstrate high TONs. ${ }^{19}$ For example, $\mathrm{Ni}^{\mathrm{II}}$ salts with DHLA (DHLA $=$ dihydrolipoic acid) have been used with CdSe nanocrystals as the photosensitiser to achieve a TON $>600,000$ over 360 h of photolysis. ${ }^{20}$

Given the very limited studies of [NiFe] containing catalysts for $\mathrm{H}_{2}$ production, we report herein detailed studies, including in situ time-resolved spectroscopic analyses, on the photoproduction of $\mathrm{H}_{2}$ from the $\left[\mathrm{NiFe}_{2}\right]$ complex, 1. Our studies focus on the electron transfer between the photosensitiser, $\left[\operatorname{ReCl}(\mathrm{CO})_{3}(\mathrm{bpy})\right],{ }^{21}$ and $\mathbf{1}$ with $\mathrm{NEt}_{3}$ or triethanolamine (TEOA) as sacrificial electron donors in $\mathrm{CH}_{3} \mathrm{CN}$, DMF and $\mathrm{CH}_{2} \mathrm{Cl}_{2}$ solutions (Scheme 1). We chose $\left[\operatorname{ReCl}(\mathrm{CO})_{3}(\mathrm{bpy})\right]$ as the photosensitiser because of its favourable photophysical, electron transfer and redox properties and because the $v(\mathrm{CO})$ IR bands of the $\left[\mathrm{ReCl}(\mathrm{CO})_{3}(\right.$ bpy $\left.)\right]$ unit provide a valuable probe by which the electron transfer can be monitored using time resolved IR spectroscopy. 


\section{Experimental}

Acetonitrile (99.9\%, Merck), $\mathrm{CH}_{2} \mathrm{Cl}_{2}$ (99.9\%, Merck) and $\mathrm{NEt}_{3}$ (> 99.5\%, Sigma-Aldrich) were distilled under an inert atmosphere of Ar from calcium hydride. Dry DMF $(99.8 \%$, < $0.005 \% \mathrm{H}_{2} \mathrm{O}$, Arcos) was used as supplied and stored in a glove box. TEOA (98\%, Alfa Aesar) was dried under reduced pressure $\left(160^{\circ} \mathrm{C}, 1 \times 10^{-1} \mathrm{mbar}\right)$ for $24 \mathrm{~h}$ before being stored under Ar. All stock solutions containing TEOA were stored over activated molecular sieves (4 ̊́) in a glove box. $\mathrm{CoCp}_{2}$ (Sigma-Aldrich) was sublimed three times and stored in a glove box. $\left[{ }^{\mathrm{n}} \mathrm{Bu}_{4} \mathrm{~N}\right]\left[\mathrm{BF}_{4}\right]$ (Sigma-Aldrich) was used as received. $\left[\operatorname{ReCl}(\mathrm{CO})_{3}(\mathrm{bpy})\right],{ }^{21}$ $\left[\mathrm{Ru}(\mathrm{bpy})_{3}\right]\left[\mathrm{PF}_{6}\right]_{2},{ }^{22}[\mathrm{HTEOA}]\left[\mathrm{BF}_{4}\right]^{23}$ and $\mathbf{1}^{10}$ were prepared according to literature methods.

Fourier Transformed Infrared Spectroscopy (FTIR): FTIR spectra were recorded in solution cells (Harrick Scientific Products, Inc.) with $\mathrm{CaF}_{2}$ windows using a Nicolet 6700 FTIR spectrometer, typically at $2 \mathrm{~cm}^{-1}$ resolution. A path length of $0.25,0.39,0.5$ or $1 \mathrm{~mm}$ was used and all solutions were prepared under an inert atmosphere of Ar and degassed by three freeze-pump-thaw cycles.

Laser Flash Photolysis: Nanosecond and picosecond time-resolved infared (TRIR) spectra were obtained using purpose-built equipment based on a pump-probe approach. Details of the equipment and methods used for the TRIR studies have been described previously, ${ }^{24}$ a brief description of which is given here. For picosecond experiments the pump beam (400 nm, ca. $150 \mathrm{fs})$ and tunable probe beam $\left(180 \mathrm{~cm}^{-1}\right.$ spectral band width, ca. $150 \mathrm{fs}$ ) were generated from a commercial Ti:sapphire oscillator (MaiTai)/regenerative amplifier system (Spitfire Pro, Spectra Physics). For nanosecond experiments the pump beam (355 nm, ca. $600 \mathrm{ps)}$ was provided by a Q-switched Nd:YVO laser (Advanced Optical Technology ACE) and the probe beam was the same as for the picosecond experiments. In both experiments the mid-IR probe was detected using a 128element $\mathrm{HgCdTe}$ array detector (Infrared Associates) typically with a resolution of 
ca. $4 \mathrm{~cm}^{-1}$. A path length of 0.5 or $1 \mathrm{~mm}$ was used and all the solutions for analysis were prepared under inert atmosphere, degassed by three freeze-pump-thaw cycles and put under 1.5 atm of Ar.

Electrochemical measurements: Electrochemical measurements were made using an Autolab PGSTAT20 potentiostat. Cyclic voltammograms of $1 \mathrm{mM}$ solutions $\left(\mathrm{CH}_{3} \mathrm{CN}\right.$, DMF and $\left.\mathrm{CH}_{2} \mathrm{Cl}_{2}\right)$ of each compound in solutions containing $\left[{ }^{\mathrm{n}} \mathrm{Bu}_{4} \mathrm{~N}\right]\left[\mathrm{BF}_{4}\right](0.2 \mathrm{M}$ in $\mathrm{CH}_{3} \mathrm{CN}$ and DMF, $0.4 \mathrm{M}$ in $\mathrm{CH}_{2} \mathrm{Cl}_{2}$ ) as the supporting electrolyte were recorded using a glassy carbon working electrode, a Pt wire secondary electrode, and a saturated calomel reference electrode at $293 \mathrm{~K}$, in less stated otherwise. Potentials were referenced to the $\mathrm{Fc}^{*} / \mathrm{Fc}^{*}\left(\mathrm{Fc}^{*}=\right.$ decamethylferrocene $)$ couple used as the internal standard but are reported against the $\mathrm{Fc}^{+} / \mathrm{Fc}$ couple, using an independent calibration under identical conditions. Under these conditions $\mathrm{Fc}^{*+} / \mathrm{Fc}^{*}$ vs. $\mathrm{Fc}^{+} / \mathrm{Fc}$ was $-0.498 \mathrm{~V},-0.471 \mathrm{~V}$ and $-0.522 \mathrm{~V}$ in $\mathrm{CH}_{3} \mathrm{CN}, \mathrm{DMF}$ and $\mathrm{CH}_{2} \mathrm{Cl}_{2}$, respectively. Coulometric studies, at a controlled potential, were carried out using a two-compartment cell. The $\mathrm{Pt} / \mathrm{Rh}$ gauze basket working electrode was separated from the wound $\mathrm{Pt} / \mathrm{Rh}$ gauze secondary electrode by a glass frit. A saturated calomel reference electrode was bridged to the test solution through a vycor frit orientated at the centre of the working electrode. The working electrode compartment was fitted with a magnetic stirrer bar and the test solution was stirred rapidly during electrolysis.

$\boldsymbol{H}_{2}$ detection: In a typical experiment $\left[\mathrm{ReCl}(\mathrm{CO})_{3}(\right.$ bpy $\left.)\right](0.25 \mathrm{mM}), \mathbf{1}(0.05 \mathrm{mM})$ and TEOA (1 M) in $\mathrm{CH}_{3} \mathrm{CN}$ were prepared from thoroughly degassed stock solutions and stored under Ar. Stock solutions containing $\left[\operatorname{ReCl}(\mathrm{CO})_{3}(\right.$ bpy $\left.)\right]$ and $\mathbf{1}$ were prepared prior to each experiment and stored in the dark in a glove box. Ar was continually flowed through the solution and into a 10 port 2 position switch (VICI) at a constant flow (typically $10 \mathrm{~cm}^{3}$ $\min ^{-1}$ ), maintained using a mass flow controller (Bronkhorst, E-Flow series). The Ar flow 
was saturated with the reaction solvent before it entered the photolysis cell. A $200 \mu \mathrm{L}$ sample was analyzed automatically every 4.5 min using a gas chromatograph (Shimadzu 2014) with a thermal conductivity detector operating at $50{ }^{\circ} \mathrm{C}$. The sample was initially passed through a pre-column (silica) to remove any condensable solvents, which were subsequently back flushed away to vent prior to the next measurement. Ar was used as the carrier gas and $\mathrm{H}_{2}$ was detected on an activated molecular sieve column (Shimadzu, CTR-1).

The $\mathrm{H}_{2}$ detection was calibrated by dosing the system with known concentrations of $\mathrm{H}_{2}$ using a 6 port 2 position switch (VICI). $\mathrm{H}_{2}$ (Air Products, Premier Plus) at 29.5 psi was used to fill a $5 \mu \mathrm{L}$ loop and subsequently switched into the Ar flow $\left(10 \mathrm{~cm}^{3} \mathrm{~min}^{-1}\right)$ at 14.5 psi. Using the difference in $\mathrm{H}_{2}$ density between the sample loop and the Ar flow at $293 \mathrm{~K}$, and the switching repeat time $(2-30 \mathrm{~s})$, the molar dosing rate of $\mathrm{H}_{2}$ could be calculated. For low dosing rates $\left(<2.5 \times 10^{-8} \mathrm{~mol} \mathrm{~min}^{-1}\right) 5 \% \mathrm{H}_{2}$ in $\mathrm{Ar}$ (BOC, Special Gases) was used, the extra Ar was accounted for by a reduction of the Ar flow at the mass flow controller. When $\mathrm{H}_{2}$ was dosed at a constant rate this gave a constant peak area in the chromatogram, varying this flow gave linear fits with the peak area. At a constant $\mathrm{H}_{2}$ flow rate $\left(2.2 \times 10^{-8} \mathrm{~mol} \mathrm{~min}^{-1}\right)$ the peak area also varied linearly with the Ar flow. Integration of a plot of the production rate versus time yields the total amount of $\mathrm{H}_{2}$ produced.

Irradiation was performed using a Xe arc lamp (Oriel Instruments) operated at $250 \mathrm{~W}$ that illuminates an area of $3 \mathrm{~cm}^{2}$. The emitted light collimated and filtered using a $2.5 \mathrm{~cm}$ water filter and a $\lambda<420 \mathrm{~nm}$ Pyrex cut-off filter before it illuminates the custom built cuvette (Helma Analytics, 221-BF).

DFT Calculations: Optimised geometries and frequencies were calculated using the QChem quantum-chemical software package. ${ }^{25}$ The PBE0 exchange-correlation functional was used $^{26}$ together with the triple- $\zeta$ quality Stuttgart relativistic small core pseudopotential and basis set combination for $\mathrm{Fe}$ and $\mathrm{Ni}$ atoms, ${ }^{27}$ and the $6-311 \mathrm{G}(\mathrm{d})$ basis 
set for atoms $\mathrm{H}, \mathrm{C}, \mathrm{O}$ and $\mathrm{S} .{ }^{28}$ The default SG-1 numerical integration grid was used for evaluation of the exchange-correlation energy in order to make the calculations more computationally tractable. ${ }^{29}\left[\mathrm{NiFe}_{2}\right]\left(\left[\mathrm{Ni}(\mathrm{L}) \mathrm{Fe}_{2}(\mathrm{CO})_{6}\right]\right)$ models were constructed using the unmethylated $\left[\mathrm{NiFe}_{2}\right]$ analogue $\mathrm{L}^{2-}=\left(\mathrm{C}_{6} \mathrm{H}_{4} \mathrm{~S}_{2}\right)_{2}\left(\mathrm{CH}_{2}\right)_{3}$, as opposed to $\mathrm{L}^{2-}=$ $\left(\mathrm{CH}_{3} \mathrm{C}_{6} \mathrm{H}_{3} \mathrm{~S}_{2}\right)_{2}\left(\mathrm{CH}_{2}\right)_{3}$, in order to reduce the computational time. The initial molecular structures for the neutral and anionic species of the model $\left[\mathrm{NiFe}_{2}\right]$ complex were optimised to minimum energy geometries using tightened energy convergence criteria of $1 \times 10^{-7} \mathrm{E}_{\mathrm{h}}$, and a gradient convergence of $1 \times 10^{-6} \mathrm{E}_{\mathrm{h}} \mathrm{a}_{0}{ }^{-1}$. Harmonic frequencies were obtained by adding numerical second derivatives of the nuclear energy with respect to displacement, calculated by finite difference of the analytical gradient $\left(0.00189 \mathrm{a}_{0}\right.$ step size) to analytical second derivatives of the electronic energy. The resulting harmonic frequencies were scaled by a uniform factor of 1.011 determined by least squares fitting. ${ }^{30}$ Calculations involving the neutral and anionic species were performed using restricted and unrestricted DFT, respectively. 


\section{Results and Discusion}

\section{Photoinduced electron transfer between $\mathrm{NEt}_{3},\left[\operatorname{ReCl}(\mathrm{CO})_{3}(\mathrm{bpy})\right]$ and 1 in $\mathrm{CH}_{3} \mathrm{CN}$}

TRIR spectroscopy: We have used fast time-resolved infrared spectroscopy (TRIR), a combination of flash photolysis with fast IR detection, ${ }^{31}$ to monitor the proposed transient species involved in the generation of $\mathbf{1}^{--}$in Scheme 1 in $\mathrm{CH}_{3} \mathrm{CN}$. The photophysics of $\mathbf{1}$ (1 $\mathrm{mM}$ ) was investigated using TRIR in $\mathrm{CH}_{3} \mathrm{CN}$. Irradiation at $355 \mathrm{~nm}$ produces a shortlived transient observed at time delays $<1 \mathrm{~ns}$ with IR bands that are red-shifted relative to the parent $\left(2025,1988,1942\right.$ and $\left.1906 \mathrm{~cm}^{-1}\right)$ and these bands rapidly recombine to form those of 1 with a lifetime of $c a .90$ ps (Figure S1). These results are similar to recently reported TRIR results for $\mathrm{Fe}_{3}(\mathrm{CO})_{12}$ which show a similar short lived transient associated with the homolysis of at least one of the FeFe bonds. ${ }^{32}$ Following the reformation of $\mathbf{1}$ there are no more observable photoproducts on the nanosecond timescale. Thus, subsequent TRIR investigations are not complicated by the intrinsic photochemistry of $\mathbf{1}$.

To investigate whether the addition of $\left[\mathrm{ReCl}(\mathrm{CO})_{3}(\mathrm{bpy})\right]$ and $\mathrm{NEt}_{3}$ affects the photochemistry of $\mathbf{1}$, the TRIR experiment was repeated in the presence of $\left[\operatorname{ReCl}(\mathrm{CO})_{3}(\mathrm{bpy})\right]$ and $\mathrm{NEt}_{3}$. The FTIR spectrum of $1(0.76 \mathrm{mM})$ and $\left[\operatorname{ReCl}(\mathrm{CO})_{3}(\mathrm{bpy})\right]$ $(0.75 \mathrm{mM})$ in a solution of $\mathrm{NEt}_{3}(1 \mathrm{M})$ and $\mathrm{CH}_{3} \mathrm{CN}$ [Figure 1(a)] possesses 6 carbonyl bands, the bands at 2035, 1994 and $1955 \mathrm{~cm}^{-1}$ are assigned to $\mathbf{1}$ and the bands at 2023, 1917 and $1900 \mathrm{~cm}^{-1}$ are associated with $\left[\operatorname{ReCl}(\mathrm{CO})_{3}(\mathrm{bpy})\right]$. The IR spectrum taken $1.5 \mathrm{~ns}$ after photolysis at $355 \mathrm{~nm}$ only shows bleaching of the bands assigned to $\left[\operatorname{ReCl}(\mathrm{CO})_{3}(\mathrm{bpy})\right]$ and transient $v(\mathrm{CO})$ peaks are observed at 2068, 1989 and $1954 \mathrm{~cm}^{-1}$ [Figure 1(b)]. These new bands are shifted to higher energy relative to those of the 


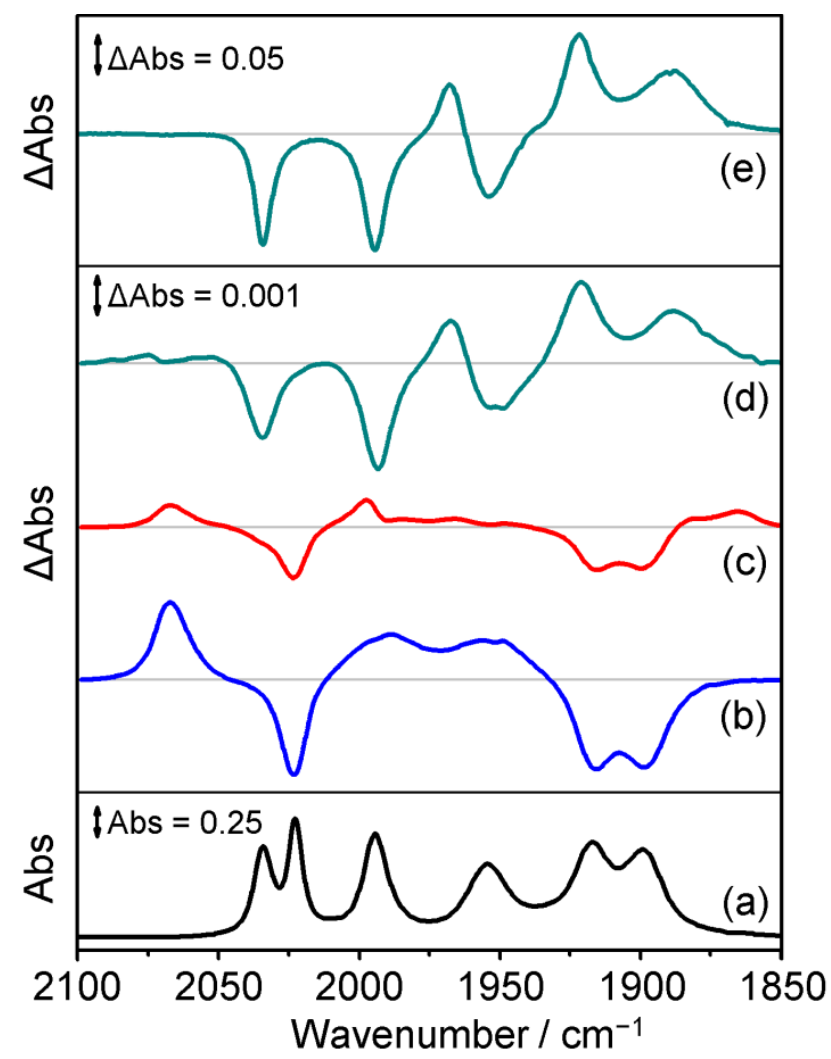

Fig. 1. FTIR and TRIR spectra of $1(0.76 \mathrm{mM})$ and $\left[\operatorname{ReCl}(\mathrm{CO})_{3}(\mathrm{bpy})\right](0.75 \mathrm{mM})$ in a solution of $\mathrm{CH}_{3} \mathrm{CN}$ and $\mathrm{NEt}_{3}(1 \mathrm{M})$. (a) FTIR ground state spectrum. TRIR difference spectra (b) $1.5 \mathrm{~ns}$, (c) $20 \mathrm{~ns}$ and (d) $500 \mathrm{~ns}$ after flash photolysis at $355 \mathrm{~nm}$. (e) FTIR difference spectrum obtained 5 seconds after 30 seconds irradiation of an identical solution using a LED white light source and a $\lambda<420 \mathrm{~nm}$ cut-off filter.

parent $\left[\mathrm{ReCl}(\mathrm{CO})_{3}(\mathrm{bpy})\right]$ complex, consistent with the formation of the ${ }^{3} \mathrm{MLCT}$ excited state, $\left[\operatorname{ReCl}(\mathrm{CO})_{3}(\mathrm{bpy})\right]^{*}{ }^{33}$ At this early time there is no change in the intensity and energies of the bands associated with the $\left[\mathrm{NiFe}_{2}\right]$ cluster, 1. In the presence of $\mathrm{NEt}_{3}$, $\left[\mathrm{ReCl}(\mathrm{CO})_{3}(\mathrm{bpy})\right]^{*}$ is reductively quenched to form the one-electron reduced photosensitiser $\left[\operatorname{ReCl}(\mathrm{CO})_{3}(\mathrm{bpy})\right]^{--}\left(1997,1880\right.$ and $\left.1864 \mathrm{~cm}^{-1}\right)$ such that the TRIR spectrum obtained at $20 \mathrm{~ns}$ is dominated by this one-electron reduced species [Figure $1(\mathrm{c})] .{ }^{34}\left[\mathrm{ReCl}(\mathrm{CO})_{3}(\mathrm{bpy})\right]^{--}$is stable for $>1 \mathrm{~s}$ in the absence of an oxidant in solution but in the presence of $1\left[\operatorname{ReCl}(\mathrm{CO})_{3}(\mathrm{bpy})\right]^{\cdot-}$ reacts rapidly on the nanosecond timescale with the concomitant bleaching of the $v(\mathrm{CO})$ bands of $\mathbf{1}$ and the formation of a new species 
with bands at 1968, 1921 and $1890 \mathrm{~cm}^{-1}$ [Figure 1(d)]. This new species can be assigned to the formation of the one-electron reduced form of $\mathbf{1}, \mathbf{1 a}^{\mathbf{}^{-}}$, by comparison with IR spectra derived from spectroelectrochemical experiments; in addition, the electrochemical experiments show a broad band at $1779 \mathrm{~cm}^{-1}$ associated with $\mathbf{1 a}^{\cdot-}$ but which falls outside the spectral window of the TRIR study. ${ }^{10}$ Another isomer of the reduced form of $\mathbf{1}, \mathbf{1 b}^{\mathbf{0}^{-}}$, can be detected under certain conditions. Proposed structures for both $1 \mathbf{a}^{\cdot-}$ and $\mathbf{1 \mathbf { b } ^ { - - }}$ are discussed later in the text.

The quenching of the ${ }^{3} \mathrm{MLCT}$ state of $\left[\operatorname{ReCl}(\mathrm{CO})_{3}(\mathrm{bpy})\right]^{*}$ can be clearly evaluated in the TRIR kinetics of the electron transfer process, obtained via multiple band fitting of the TRIR spectra (Figure 2).

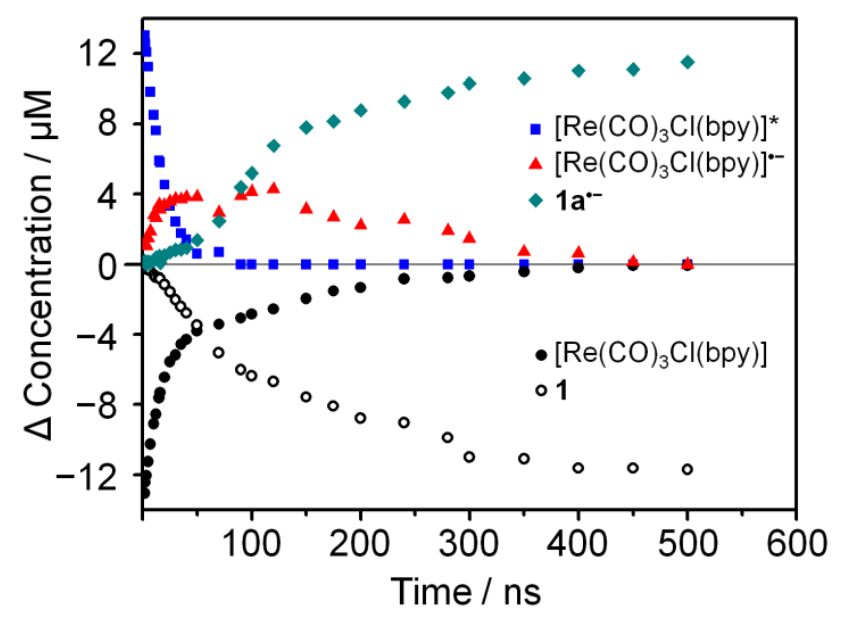

Fig. 2. TRIR kinetic traces for the decay of the ${ }^{3} \mathrm{MLCT}$ excited state $\left[\operatorname{ReCl}(\mathrm{CO})_{3}(\mathrm{bpy})\right]^{*}$ (blue squares); the growth and decay of $\left[\operatorname{ReCl}(\mathrm{CO})_{3}(\text { bpy })\right]^{--}$(red triangles), the growth of $\mathbf{1 a}^{\circ}$ (green diamonds), the regeneration of $\left[\operatorname{ReCl}(\mathrm{CO})_{3}(\right.$ bpy) $]$ (black dots) and the loss of 1 (circles) recorded in $\mathrm{CH}_{3} \mathrm{CN}$ following flash photolysis $(355 \mathrm{~nm})$ of $\mathbf{1}(0.76 \mathrm{mM})$ and $\left[\operatorname{ReCl}(\mathrm{CO})_{3}(\right.$ bpy $\left.)\right](0.75 \mathrm{mM})$ in a solution of $\mathrm{NEt}_{3}(1 \mathrm{M})$ and $\mathrm{CH}_{3} \mathrm{CN}$.

Assuming that the formation of $\left[\operatorname{ReCl}(\mathrm{CO})_{3}(\mathrm{bpy})\right]^{*}$ and the subsequent growth of $\mathbf{1 a}^{\cdot-}$ are the only significant processes that occur, and that these are represented by the loss of $\left[\operatorname{ReCl}(\mathrm{CO})_{3}(\mathrm{bpy})\right]$ and $\mathbf{1}$, respectively, then the band areas can be used to estimate the concentrations of each species in solution. The ${ }^{3} \mathrm{MLCT}$ state in $\left[\operatorname{ReCl}(\mathrm{CO})_{3}(\mathrm{bpy})\right]^{*}$ is formed 
within the timescale of these experiments and decays with a lifetime of $17( \pm 0.3)$ ns (Figure 2 and Figure $\mathrm{S} 2$, blue squares) and is accompanied by the reformation of $\left[\operatorname{ReCl}(\mathrm{CO})_{3}(\mathrm{bpy})\right]$ (Figure 2, black dots). This parent re-growth occurs through two processes, the first of which (representing $\mathrm{ca} .70 \%$ of the re-growth) is associated with the relaxation of $\left[\operatorname{ReCl}(\mathrm{CO})_{3}(\text { bpy })\right]^{*} \rightarrow\left[\operatorname{ReCl}(\mathrm{CO})_{3}(\right.$ bpy $\left.)\right]$. The growth of $\left[\operatorname{ReCl}(\mathrm{CO})_{3}(\text { bpy })\right]^{--}$is observed (Figure 2, red triangles) simultaneously and on longer timescales (50-500 ns). $\left[\mathrm{ReCl}(\mathrm{CO})_{3}(\mathrm{bpy})\right]^{--}$reduces $\mathbf{1}$ and the remaining $\left[\mathrm{ReCl}(\mathrm{CO})_{3}(\mathrm{bpy})\right]$ is recovered, which accounts for the remaining $30 \%$ of the re-growth of $\left[\operatorname{ReCl}(\mathrm{CO})_{3}(\right.$ bpy) $] .1$ is lost (Figure 2, circles) and $1 \mathbf{a}^{\mathbf{0}^{-}}$is formed (Figure 2, green diamonds) such that the IR spectrum obtained at $500 \mathrm{~ns}$ is dominated by $\mathbf{1 \mathbf { a } ^ { - - }}$. The sigmoidal growth of $\mathbf{1 a}^{\mathbf{a}^{-}}$is consistent with its formation from an intermediate species, namely $\left[\mathrm{ReCl}(\mathrm{CO})_{3}(\mathrm{bpy})\right]^{--}$(Scheme 1). Thus, electron transfer from $\left[\operatorname{ReCl}(\mathrm{CO})_{3}(\mathrm{bpy})\right]^{--}$to $\mathbf{1}$ forms $\mathbf{1 a}^{\cdot-}$, which remains stable on the timescale of this experiment (up to $0.1 \mathrm{~ms}$ ). On the basis of our TRIR spectroscopic results, we estimate that the second order rate constant, $k_{\text {inter }}$, for electron transfer between $\left[\operatorname{ReCl}(\mathrm{CO})_{3}(\mathrm{bpy})\right]^{--}$ and 1 as $k_{\text {inter }}=6.7 \times 10^{9} \mathrm{M}^{-1} \mathrm{~s}^{-1}$ (Figure S2). Control experiments involving the irradiation of a solution of $\mathbf{1}$ and $\left[\mathrm{ReCl}(\mathrm{CO})_{3}(\mathrm{bpy})\right]$ in $\mathrm{CH}_{3} \mathrm{CN}$ show no direct interaction between $\mathbf{1}$ and the excited state of the photosensitiser; under these conditions the presence of $1 \mathbf{a}^{\mathbf{}^{-}}$was not observed.

The upper limits of the concentration of $\mathbf{1 a}^{\cdot-}$ and $\left[\operatorname{ReCl}(\mathrm{CO})_{3}(\mathrm{bpy})\right]^{\mathbf{0}^{-}}$are estimated as $c a$. 11 and ca. $5 \mu \mathrm{M}$, respectively (Figure 2), suggesting that the concentration of $\mathbf{1 a}^{\cdot-}$ reaches a value $c a$. double of that of $\left[\operatorname{ReCl}(\mathrm{CO})_{3}(\mathrm{bpy})\right]^{0^{-}}$. However, according to Scheme 1 , the maximum concentration for $\mathbf{1 a}^{\mathbf{0}^{-}}$and $\left[\operatorname{ReCl}(\mathrm{CO})_{3}(\mathrm{bpy})\right]^{\mathbf{0}^{-}}$would be expected to have a value that was approximately equivalent. The reductive quenching of the ${ }^{3}$ MLCT excited state of $\left[\mathrm{ReCl}(\mathrm{CO})_{3}(\mathrm{bpy})\right]$ by $\mathrm{NEt}_{3}$ results in the formation of a $\mathrm{N}$-centered radical cation, ${ }^{-} \mathrm{NEt}_{3}{ }^{+}$and this species could generate a second reducing equivalent through a thermal 
dark process. Thus, the extraction of $\mathrm{H}^{\bullet}$ from another molecule of $\mathrm{NEt}_{3}$ by ${ }^{\circ} \mathrm{NEt}_{3}{ }^{+}$may result in the formation of $\mathrm{HNEt}_{3}{ }^{+}$and a strongly reducing C-centered radical, $\mathrm{CH}_{3} \mathrm{C}^{\circ} \mathrm{HNEt}_{2} .{ }^{35} \mathrm{By}$ analogy with the chemistry of radical cations formed from TEOA, ${ }^{36}$ $\mathrm{CH}_{3} \mathrm{C}^{\cdot} \mathrm{HNEt}_{2}$ could reduce either $\left[\mathrm{ReCl}(\mathrm{CO})_{3}(\right.$ bpy) $]$ or $\mathbf{1}$ and ultimately generate a second equivalent of $\mathbf{1 a}^{\cdot-35,37}$ Similar decomposition reactions have been proposed previously for TEOA and $\mathrm{NEt}_{3}$ on oxidation. ${ }^{38}$ Indeed, the decomposition of $\mathrm{TEOA}^{\bullet+}$ has been proposed to reduce $\left[\mathrm{ReX}(\mathrm{CO})_{3}(\mathrm{bpy})\right](\mathrm{X}=\mathrm{Cl}, \mathrm{Br})$ in $\mathrm{DMF} .^{36,39}$ In addition, alkyl radicals of $\mathrm{NEt}_{3}$ have also been identified by spin trapping following the continuous irradiation of $\mathrm{NEt}_{3}$ and $\mathrm{Ru}(\mathrm{II})$ polypyridyl complexes in $\mathrm{DMF}{ }^{35}$

\section{Photoinduced electron transfer between $\mathrm{NEt}_{3},\left[\operatorname{ReCl}(\mathrm{CO})_{3}(\mathrm{bpy})\right]$ and 1 in $\mathrm{CH}_{3} \mathrm{CN}$, DMF and $\mathrm{CH}_{2} \mathrm{Cl}_{2}$}

FTIR spectroscopy: The formation of $\mathbf{1 a}^{\cdot-}$ was probed by FTIR spectroscopy using white light irradiation from a visible LED light source (20-30 s with a $\lambda>420 \mathrm{~nm}$ Pyrex glass filter) under Ar. The FTIR spectrum of $1(1 \mathrm{mM})$ and $\left[\operatorname{ReCl}(\mathrm{CO})_{3}(\mathrm{bpy})\right](1 \mathrm{mM})$ in a solution of $\mathrm{NEt}_{3}(1 \mathrm{M})$ and $\mathrm{CH}_{3} \mathrm{CN}$ obtained $5 \mathrm{~s}$ after photolysis [Figure 3(a) and Figure 1(e), green lines] clearly shows the presence of bands assigned to $\mathbf{1 a}^{\mathbf{*}^{-}}$, and is identical to the TRIR spectra obtained after $10 \mu \mathrm{s}$ [Figure $1(\mathrm{~d})] .{ }^{10}$ There are no significant changes in the bands associated with the photosensitiser, consistent with its regeneration in the catalytic cycle (Scheme 1). Control experiments, in which either $\mathrm{NEt}_{3}$ or $\left[\operatorname{ReCl}(\mathrm{CO})_{3}(\mathrm{bpy})\right]$ were absent from the test solution, lead to no significant changes in the IR spectrum after photolysis. Thus $\left[\operatorname{ReCl}(\mathrm{CO})_{3}(\mathrm{bpy})\right], \mathbf{1}$ and $\mathrm{NEt}_{3}$ are all necessary for the complete electron transfer cycle. 

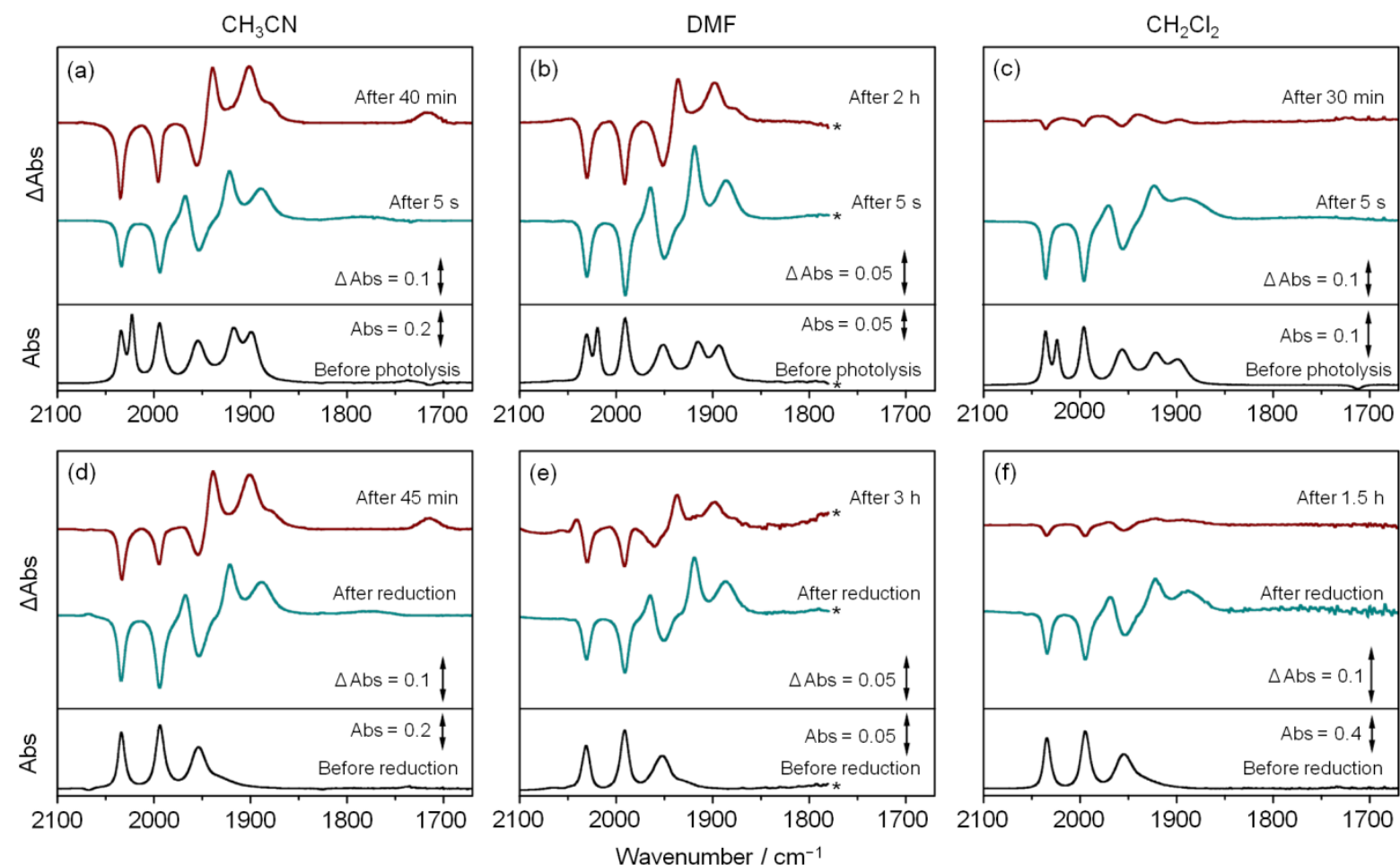

Fig. 3. FTIR spectra comparing the photochemical [top row, (a), (b) and (c)] and electrochemical [bottom row, (d), (e) and (f)] reduction of $\mathbf{1}$ to $\mathbf{1 a}^{\cdot--}$ and $\mathbf{1 b}^{\mathbf{0}^{-}}$. Top row; FTIR ground state spectra of $1(1 \mathrm{mM})$ and $\left[\operatorname{ReCl}(\mathrm{CO})_{3}(\mathrm{bpy})\right](1 \mathrm{mM})$ in a solution of $\mathrm{NEt}_{3}(1 \mathrm{M})$ and $\mathrm{CH}_{3} \mathrm{CN}$ (a), DMF (b) and $\mathrm{CH}_{2} \mathrm{Cl}_{2}$ (c) (black lines). FTIR difference spectra of $1 \mathbf{a}^{-0} 5 \mathrm{~s}$ after photochemical reduction (between 20 and 30 s photolysis time) according to Scheme 1 (green lines). FTIR difference spectra of $\mathbf{1 b}^{\mathbf{0}^{-}} 40$ min after photolysis in $\mathrm{CH}_{3} \mathrm{CN}, 2 \mathrm{~h}$ after photolysis in DMF and 30 min after photolysis in $\mathrm{CH}_{2} \mathrm{Cl}_{2}$ (brown lines in (a), (b) and (c), respectively). Bottom row; FTIR ground state spectra of $\mathbf{1}(1 \mathrm{mM})$ in a solution in $\mathrm{CH}_{3} \mathrm{CN}$ (a), DMF (b) and $\mathrm{CH}_{2} \mathrm{Cl}_{2}$ (c) containing [ $\left.{ }^{\mathrm{n}} \mathrm{Bu}_{4} \mathrm{~N}\right]\left[\mathrm{BF}_{4}\right]\left(0.2 \mathrm{M}\right.$ in $\mathrm{CH}_{3} \mathrm{CN}$ and DMF, $0.4 \mathrm{M}$ in $\mathrm{CH}_{2} \mathrm{Cl}_{2}$ ) as supporting electrolyte (black lines). FTIR difference spectra of $\mathbf{1 a}^{--}$after electrochemical reduction in $\mathrm{CH}_{3} \mathrm{CN}$ (d), DMF (e) and $\mathrm{CH}_{2} \mathrm{Cl}_{2}$ (f) (green lines). FTIR difference spectra of $\mathbf{1 b}^{--} 45$ min after reduction in $\mathrm{CH}_{3} \mathrm{CN}, 3 \mathrm{~h}$ after reduction in DMF and $1.5 \mathrm{~h}$ after reduction in $\mathrm{CH}_{2} \mathrm{Cl}_{2}$ (brown lines in (d), (e) and (f), respectively). To facilitate comparison with the photochemical experiments, the spectra for electrochemically generated $\mathbf{1 b}^{\mathbf{*}}$ in $\mathrm{CH}_{3} \mathrm{CN}$ and DMF are generated through the partial spectral subtraction of $\mathbf{1 a}^{\mathbf{*}}$. Solvent bands of DMF are omitted for clarity.

The photocatalytic production of $\mathbf{1 a}^{\cdot-}$ from $\mathbf{1}$ also occurs in DMF and $\mathrm{CH}_{2} \mathrm{Cl}_{2}$ solutions [Figure 3(b) and Figure 3(c), green lines]. Once formed, however, $\mathbf{1 a}^{\cdot-}$ is not stable but 
undergoes subsequent transformations over timescales of up to $3 \mathrm{~h}$ depending on the nature of the solvent. In $\mathrm{CH}_{3} \mathrm{CN}$ and DMF solutions the bands associated with the parent bleach remain constant whilst those of $\mathbf{1 a}^{\cdot-}$ decrease in intensity. The formation of a new product with $v(\mathrm{CO})$ bands at 1992, 1939, 1901, 1880 and $1714 \mathrm{~cm}^{-1}$ in $\mathrm{CH}_{3} \mathrm{CN}$ and 1989 , 1936, 1898 and $1878 \mathrm{~cm}^{-1}$ in DMF is observed [Figure 3(a) and Figure 3(b) after 40 min and $2 \mathrm{~h}$, respectively, brown lines]. The red shift $\left(\mathrm{ca} .50 \mathrm{~cm}^{-1}\right)$ of the band positions of this new product relative to those of $\mathbf{1}$, together with electrochemical data (see below), have led to the assignment of this new species, $\mathbf{1 b}^{\mathbf{}}$, as an overall one-electron reduced product of $\mathbf{1}$ at the same oxidation state level as $\mathbf{1 a}^{--}$. The band at $1714 \mathrm{~cm}^{-1}$ in $\mathrm{CH}_{3} \mathrm{CN}$ solution suggests the formation of a bridging metal carbonyl species; this band is not observed in DMF due to strong solvent absorbance in this region [Figure 3(b), brown line]. In $\mathrm{CH}_{2} \mathrm{Cl}_{2}$ solution the bands associated with $\mathbf{1 a}^{--}$decrease in intensity and are accompanied by the re-growth of bands for $\mathbf{1}$ such that the difference spectrum [Figure 3(c), brown line] $1.5 \mathrm{~h}$ after photolysis shows only weak negative features associated with 1 and weak positive features at $c a$. 1898, 1941 and $1980 \mathrm{~cm}^{-1}$. The bands at 1941 and $1980 \mathrm{~cm}^{-1}$ could indicate the formation of a small quantity of $\mathbf{1 b}^{\cdot-}$ in $\mathrm{CH}_{2} \mathrm{Cl}_{2}$. However, due to the weak intensity of these bands further investigation is required to unequivocally determine their origin.

We have probed the formation of $\mathbf{1 b}^{\mathbf{0}^{-}}$from $\mathbf{1 a}^{\mathbf{}^{-}}$by electrochemical and chemical reduction of 1 in $\mathrm{CH}_{3} \mathrm{CN}$, DMF and $\mathrm{CH}_{2} \mathrm{Cl}_{2}$ solutions. The cyclic voltammetry of $\mathbf{1}$ shows a reduction process at $\mathrm{E}_{1 / 2}=-1.20,-1.19$ and $-1.29 \mathrm{~V} v s$. $\mathrm{Fc}^{+} / \mathrm{Fc}$ in $\mathrm{CH}_{3} \mathrm{CN}, \mathrm{DMF}$ and $\mathrm{CH}_{2} \mathrm{Cl}_{2}$, respectively (Figure $\mathrm{S} 4$ ), which is electrochemically reversible in all three solvents and consistent with reported values in $\mathrm{CH}_{2} \mathrm{Cl}_{2}\left(\mathrm{E}_{1 / 2}=-1.31 \mathrm{~V}\right.$ vs. $\left.\mathrm{Fc}^{+} / \mathrm{Fc}\right) .{ }^{10} \mathrm{The}$ reduction process in $\mathrm{CH}_{3} \mathrm{CN}$, DMF and $\mathrm{CH}_{2} \mathrm{Cl}_{2}$ solutions was investigated by monitoring the FTIR spectrum of $\mathbf{1}$ after electrochemical reduction. In $\mathrm{CH}_{2} \mathrm{Cl}_{2}$ solution, the 
electrochemical reduction of $\mathbf{1}$ at $-1.54 \mathrm{~V} v s \mathrm{Fc}^{+} / \mathrm{Fc}$ results in the formation of $\mathbf{1 a}^{\cdot-}$, which is oxidised back to $\mathbf{1}$ over $1.5 \mathrm{~h}$, presumably by the ingress of dioxygen [Figure 3(f), brown line]. In $\mathrm{CH}_{3} \mathrm{CN}$ and DMF solutions electrochemical reduction of $\mathbf{1}$ at -1.42 and $1.49 \mathrm{~V} v s \mathrm{Fc}^{+} / \mathrm{Fc}$, repectively, also results in the formation of $\mathbf{1 a}^{\cdot-}$ which subsequently converts to $\mathbf{1 b}^{\mathbf{}^{-}}$[Figure 3(d) and Figure 3(e), brown lines] as observed in the photochemical reactions [Figure 3(a) and Figure 3(b), brown lines]. Cyclic voltammograms recorded on the solutions after reduction $\left(45 \mathrm{~min}\right.$ in $\mathrm{CH}_{3} \mathrm{CN}$ and $3 \mathrm{~h}$ in DMF) show an oxidation process at $\mathrm{E}_{\mathrm{p}}{ }^{\mathrm{a}}=-0.59$ and $-0.52 \mathrm{~V}$ vs. $\mathrm{Fc}^{+} / \mathrm{Fc}$ in $\mathrm{CH}_{3} \mathrm{CN}$ and DMF, respectively, associated with the presence of $\mathbf{1 b}^{\mathbf{0}^{-}}$(Figure 4). This new process, assigned to the oxidation of $\mathbf{1 b}^{\cdot-}$, has a small associated reduction process at $\mathrm{E}_{\mathrm{p}}{ }^{\mathrm{c}}=-0.73$ $\mathrm{V}$ vs. $\mathrm{Fc}^{+} / \mathrm{Fc}$ in $\mathrm{CH}_{3} \mathrm{CN}$. In DMF no associated reduction process was observed [Figure 4(b)]; however, the cathodic current associated with the conversion of $\mathbf{1}$ to $\mathbf{1 a}^{\cdot-}$ is increased $\left(\mathrm{E}_{\mathrm{p}}^{\mathrm{c}}=-1.23 \mathrm{~V}\right.$ vs. $\left.\mathrm{Fc}^{+} / \mathrm{Fc}\right)$, suggesting that oxidation of $\mathbf{1} \mathbf{b}^{\cdot-}$ has reformed $\mathbf{1}$.

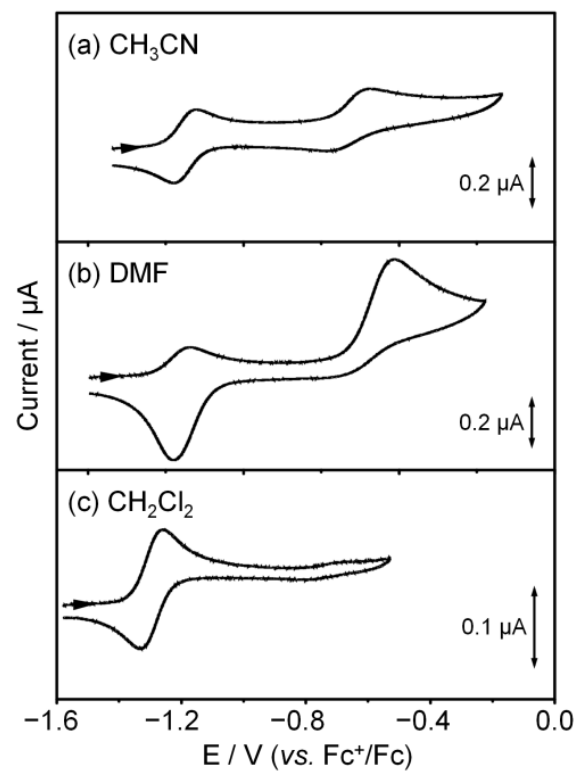

Fig. 4. Cyclic voltammograms following bulk reduction of $\mathbf{1}$ in (a) $\mathrm{CH}_{3} \mathrm{CN}\left(\mathbf{1 a}^{\mathbf{0}}\right.$ and $\mathbf{1 b}^{\mathbf{0}^{-}}$in

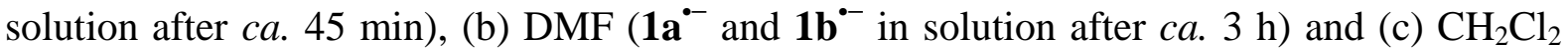
$\left(\mathbf{1 a}^{--}\right.$and $\mathbf{1}$ in solution) at $298 \mathrm{~K}$, containing $\left[{ }^{\mathrm{n}} \mathrm{Bu}_{4} \mathrm{~N}\right]\left[\mathrm{BF}_{4}\right]\left(0.2 \mathrm{M}\right.$ in $\mathrm{CH}_{3} \mathrm{CN}$ and DMF, $0.4 \mathrm{M}$ in $\mathrm{CH}_{2} \mathrm{Cl}_{2}$ ) as a supporting electrolyte at a scan rate of $100 \mathrm{mV} \mathrm{s}^{-1}$. 
The chemical reduction of $\mathbf{1}$ by $\mathrm{CoCp}_{2}\left(\mathrm{Cp}^{-}=\right.$cyclopentadienyl $)$generates $\mathbf{1 a}^{\cdot-}$ in $\mathrm{CH}_{3} \mathrm{CN}$ and DMF solutions which then converts to $\mathbf{1 b}^{--}$. The growth of $\mathbf{1 b}^{\mathbf{}^{--}}$in $\mathrm{CH}_{3} \mathrm{CN}$ and DMF solution follows a first order process with lifetimes of $516( \pm 6)$ and $6360( \pm$ 100) $\mathrm{s}\left[k_{a b}=19.4( \pm 0.2)\right.$ and $\left.1.57( \pm 0.02) \times 10^{-4} \mathrm{~s}^{-1}\right]$ in $\mathrm{CH}_{3} \mathrm{CN}$ and DMF, respectively [Figure 5(d), brown dots]. These results, and the first order nature of the process, suggest that the species $\mathbf{1 b}^{\cdot-}$ is not formed from a dimer produced from two $\mathbf{1 a}^{\cdot-}$ molecules, a process that has been observed following the reduction of $(\mu-\mathrm{pdt})\left[\mathrm{Fe}(\mathrm{CO})_{3}\right]_{2}\left(\mathrm{pdt}^{2-}=\right.$ $\left.\mathrm{S}\left(\mathrm{CH}_{2}\right)_{3} \mathrm{~S}^{-}\right) .^{40}$ In $\mathrm{CH}_{3} \mathrm{CN}$ solution, unassigned bands at 1977,1932 and $2013 \mathrm{~cm}^{-1}$ are also observed as a secondary product, consistent with the decay of $\mathbf{1 a}^{\mathbf{}^{-}}$fitting to a biexponential fit with time constants $420( \pm 5)$ and $2520( \pm 50)$ s and pre-exponential factors $0.543( \pm 0.005)$ and $0.453( \pm 0.004)$ [Figure 5(d)], respectively, where the time constant $420( \pm 5) \mathrm{s}$ is associated with the formation of $\mathbf{1 \mathbf { b } ^ { - - }}$. The formation of $\mathbf{1 \mathbf { b } ^ { - - }}$ is not accompanied by the growth of any other peaks in the $v(\mathrm{CO})$ region of the IR spectrum in DMF solution. 

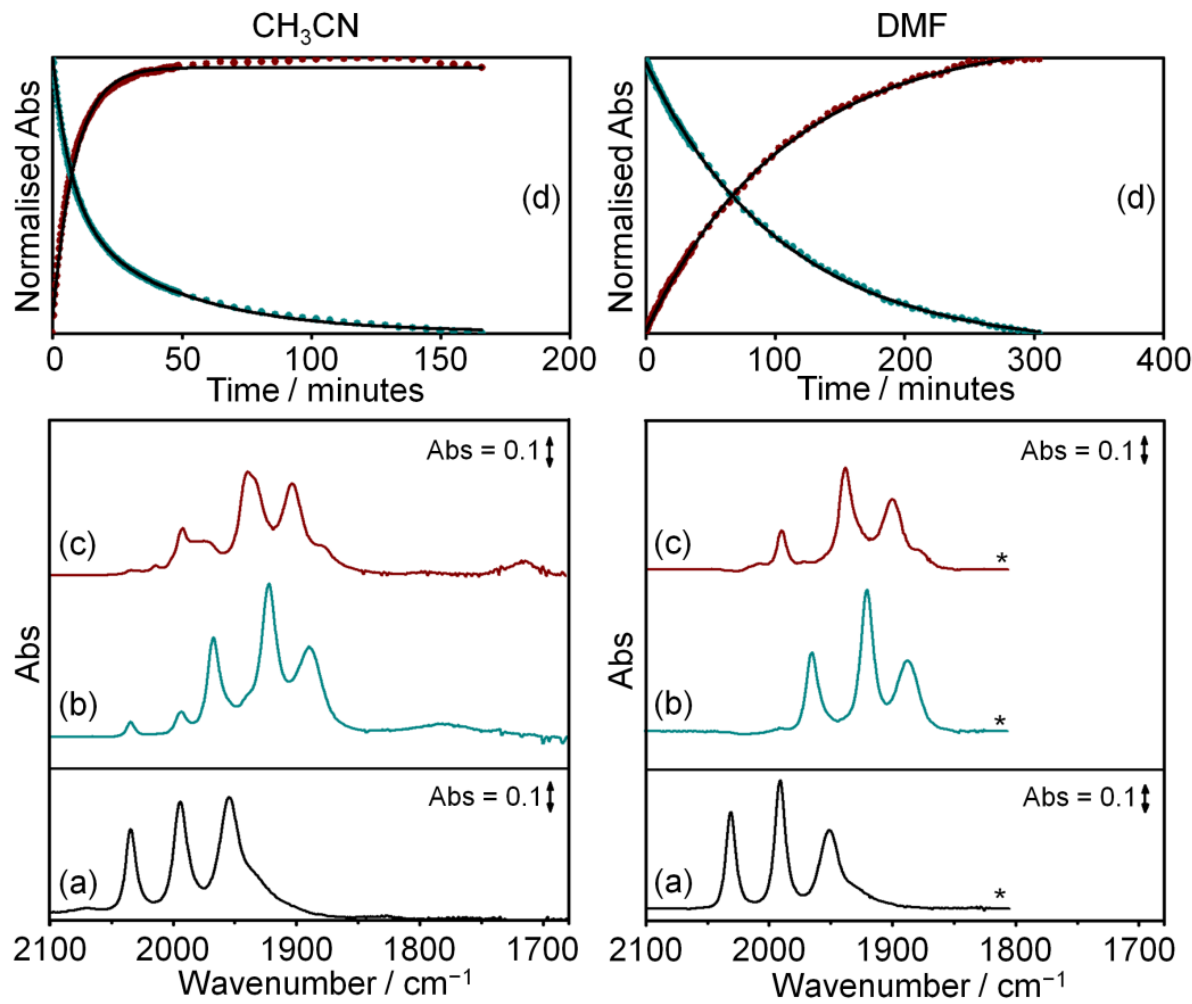

Fig. 5. FTIR spectra of $\mathbf{1 a}^{\mathbf{0}^{-}}$and $\mathbf{1 \mathbf { b } ^ { - - }}$ generated after chemical reduction of $\mathbf{1}$ with $\mathrm{CoCp}_{2}$ in $\mathrm{CH}_{3} \mathrm{CN}$ (left) and DMF (right). (a) FTIR ground state spectra of 1 (2 mM). (b) FTIR spectra of $\mathbf{1 a}^{--} 5 \mathrm{~s}$ following chemical reduction with $\mathrm{CoCp}_{2}\left(2\right.$ and $2.1 \mathrm{mM}$ in $\mathrm{CH}_{3} \mathrm{CN}$ and DMF, respectively) (b) FTIR spectra after the thermal formation of $\mathbf{1 b}^{--}$in $\mathrm{CH}_{3} \mathrm{CN}$ (ca. 150 minutes) and DMF (ca. $5 \mathrm{~h}$ ). (d) single point kinetic trace following the conversion of $1 \mathbf{a}^{\mathbf{0}^{-}}$to $\mathbf{1 b}^{\mathbf{*}}, 1967$ (green dots) and 1991 (brown dots) $\mathrm{cm}^{-1}$ in $\mathrm{CH}_{3} \mathrm{CN}, 1964$ (green dots) and 1988 (brown dots) $\mathrm{cm}^{-1}$ in DMF.* Solvent bands of DMF are omitted for clarity.

After the chemical generation of $\mathbf{1 b}^{\cdot-}$ from $\mathbf{1}$ using $\mathrm{CoCp}_{2}$ in $\mathrm{CH}_{3} \mathrm{CN}$, the removal of $\mathrm{CH}_{3} \mathrm{CN}$ under reduced pressure followed by the addition of $\mathrm{CH}_{2} \mathrm{Cl}_{2}$ results in $\mathbf{1}$ being the only species that is observed in the FTIR spectrum. Thus, $\mathbf{1}$ appears to form via backelectron transfer to $\left[\mathrm{CoCp}_{2}\right]^{+}$in $\mathrm{CH}_{2} \mathrm{Cl}_{2}$ solution. This would suggest that $\mathbf{1 b}^{{ }^{--}}$is not a decomposition product from $\mathbf{1 a}^{\mathbf{0}^{-}}$and must be closely linked structurally to $\mathbf{1}$. Once formed $\mathbf{1 \mathbf { b } ^ { \cdot - }}$ slowly decomposes over $c a .8 \mathrm{~h}$ without the growth of any clearly observable new metal carbonyl bands.

DFT Calculations: We have performed density functional theory (DFT) geometry 
optimisations and harmonic frequency calculations to provide theoretical models for $\mathbf{1}$ and its reduced forms, $\mathbf{1 a}^{\cdot-}$ and $\mathbf{1} \mathbf{b}^{\cdot-}$. We were able to determine two minimum energy geometries for the one-electron reduced state and one for the neutral species. The geometries for the experimental and calculated frequencies and the experimental FTIR spectra of $\mathbf{1}, \mathbf{1 a}^{\cdot-}$ and $\mathbf{1 \mathbf { b } ^ { \circ - }}$ are shown in Table 1 and Figure 6 . The atom labelling schemes for $\mathbf{1}, \mathbf{1 a}^{\cdot-}$ and $\mathbf{1 b}^{\mathbf{0}^{-}}$are shown in Figures S5-S8.

Table 1. Photochemical FTIR $v(\mathrm{CO})$ data in $\mathrm{CH}_{3} \mathrm{CN}, \mathrm{CH}_{2} \mathrm{Cl}_{2}$ and DMF and scaled harmonic frequencies, of species relating to 1 .

\begin{tabular}{|c|c|c|c|c|}
\hline & $v(\mathrm{CO}) / \mathrm{cm}^{-1}$ & & & \\
\hline & 1 & $1 \mathbf{a}^{\cdot-}$ & $1 b^{0^{-}}$ & Reference \\
\hline $\mathrm{CH}_{3} \mathrm{CN}$ & $\begin{array}{l}2035,1994,1955 \\
1936(\mathrm{w}, \mathrm{sh})\end{array}$ & $\begin{array}{l}1968, \quad 1921,1890, \\
1779(w, b r)\end{array}$ & $1992,1939,1901,1880,1714$ & This work \\
\hline DMF & $\begin{array}{l}2031,1991,1952, \\
1936(\mathrm{w}, \mathrm{sh})\end{array}$ & $\begin{array}{l}1965, \quad 1919, \quad 1887 \\
1773(\mathrm{w}, \mathrm{br})\end{array}$ & 1989, 1936, 1898, 1878 & This work \\
\hline $\mathrm{CH}_{2} \mathrm{Cl}_{2}$ & $\begin{array}{l}2036,1996,1956 \\
1936(\mathrm{w}, \mathrm{sh})\end{array}$ & $\begin{array}{l}\text { 1967, 1923, } 1891, \\
1758(w, b r)\end{array}$ & Not observed & $\begin{array}{l}\text { Ref. } 10 \\
\text { This work }\end{array}$ \\
\hline Calculated & $\begin{array}{l}2029,1998,1973 \\
1971,1891,1867\end{array}$ & $\begin{array}{l}1956,1921,1893 \\
1890,1805,1757\end{array}$ & $\begin{array}{l}\text { 1976, 1938, 1911, 1906, } 1768 \\
(\mathrm{w}), 1702\end{array}$ & This work \\
\hline
\end{tabular}

The DFT calculations of $\mathbf{1}$ reproduce the principal features of the experimental geometry of 1 including the non-planarity of the $\mathrm{NiS}_{4}$ unit; the dihedral angle between the planes defined by atoms $\mathrm{S}(1)-\mathrm{Ni}-\mathrm{S}(2)$ and $\mathrm{S}(3)-\mathrm{Ni}-\mathrm{S}(4)\left(85.3^{\circ}\right)$ is in close agreement with the dihedral angle reported for the crystal structure $\left(85.7^{\circ}\right) .{ }^{10}$ The Ni-S(thiolate), Ni-S(thioether) and $\mathrm{Fe}-\mathrm{S}$ bonds are $c a .0 .05,0.1$ and $0.05 \AA$ longer, respectively, than the corresponding experimental distances in 1. A comparison of the experimental and calculated $\mathrm{Fe}-\mathrm{C}$ distances for the $\mathrm{CO}$ ligands defined by $\mathrm{C}(3)$ and $\mathrm{C}(4)$ (Table 1) predicts a greater degree of semibridging character in the gas phase structure. These differences between the calculated gas phase geometry and X-ray crystal structure of $\mathbf{1}$ are similar to those reported previously for DFT calculations for 1 that employed the BP86 functional. ${ }^{10}$ Thus, while the calculations 
reproduce the principal features of the bonding, we note that differences between the calculated and experimental $v(\mathrm{CO})$ (see below) may reflect the greater semi-bridging character of the $\mathrm{CO}$ ligands defined by atoms $\mathrm{C}(3)$ and $\mathrm{C}(4)$ in the calculated gas phase structure relative to the experimental geometry.

The calculated geometry of $\mathbf{1 a}^{\cdot-}$ is very similar to that calculated for $\mathbf{1}$, and is, therefore, entirely consistent with previous assignments of the one-electron reduced $\left[\mathrm{NiFe}_{2}\right]$ species. ${ }^{10}$ The changes to the overall structure include the lowering of the approximate $\mathrm{C}_{2}$ symmetry brought about by an elongation of the Ni-S(2) bond by $0.15 \AA$ compared with $0.04 \AA$ for the $\mathrm{Ni}-\mathrm{S}$ (4) bond, a $0.20 \AA$ A elongation of both Ni-Fe bonds, and minor increase in the asymmetry and apparent semi-bridging character predicted for the $\mathrm{C}(3) \mathrm{O}(3)$ and $\mathrm{C}(4) \mathrm{O}(4)$ carbonyl groups $[\mathrm{Fe}(1)-\mathrm{C}(3)=1.83 \AA, \mathrm{Fe}(2)-\mathrm{C}(4)=1.80 \AA, \mathrm{Fe}(1)-\mathrm{C}(4)=2.25 \AA$ and $\mathrm{Fe}(2)-\mathrm{C}(3)=$ $2.14 \AA$ for $\mathbf{1 a}^{\cdot-}$ ]. In contrast, on moving from $\mathbf{1 a}^{\cdot-}$ to $\mathbf{1 b}^{\cdot-}$, there is a dramatic rearrangement from semi-bridging to almost complete bridging character for the $\mathrm{C}(3) \mathrm{O}(3)$ and $\mathrm{C}(4) \mathrm{O}(4)$ ligands. The $\mathrm{Fe}-\mathrm{C}$ bond lengths for the two ligands elongate by $0.08 \AA$ and $0.11 \AA$ for the $\mathrm{Fe}(1)-\mathrm{C}(3)$ and $\mathrm{Fe}(2)-\mathrm{C}(4)$ bonds, respectively, as they move to a more symmetric bridging mode. The distance between the two Fe centres also decreases by $0.05 \AA$, and the dihedral angle between the planes defined by $\mathrm{C}(3)-\mathrm{Fe}(1)-\mathrm{Fe}(2)$ and $\mathrm{C}(4)$ $\mathrm{Fe}(1)-\mathrm{Fe}(2)$ reduces from 51 to $31^{\circ}$, increasing the planarity of the two bridging $\mathrm{CO}$ groups.

Theoretical infrared spectra and frequencies (1.011 scaling factor, Figure 6 and Table 1) for $\mathbf{1}, \mathbf{1 a}^{\mathbf{0}^{-}}$and $\mathbf{1 \mathbf { b } ^ { \circ - }}$, provide a qualitatively match for the experimental spectra of $\mathbf{1}, \mathbf{1 a}^{\mathbf{0}^{-}}$and $\mathbf{1 b}^{\cdot-}$ in $\mathrm{CH}_{3} \mathrm{CN}$ solution, and importantly reproduces the key features in each spectrum including the frequency downshift on reduction of $\mathbf{1}$ to $\mathbf{1 a}^{\mathbf{a}^{-}}$observed for all three CO bands. Similarly, the frequency increase in the $\mathrm{CO}$ bands of $\mathbf{1 b}^{\mathbf{*}}$ relative to $\mathbf{1 a}^{\mathbf{a}^{-}}$is reproduced with scaled harmonic bands moving to 1976,1938 and $1911 \mathrm{~cm}^{-1}$ for $\mathbf{1 b}^{\bullet-}$. 


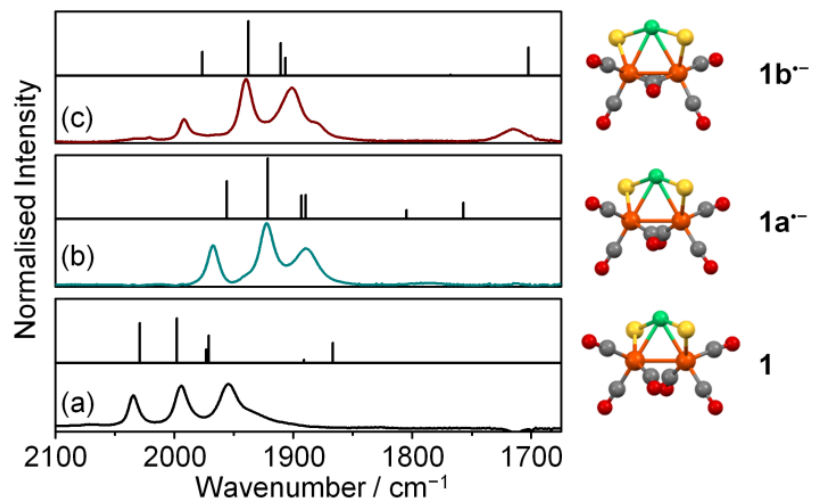

Fig. 6. Calculated scaled harmonic vibrational frequencies above the experimental $v(\mathrm{CO})$ data as observed by FTIR in $\mathrm{CH}_{3} \mathrm{CN}$ (left). Predicted geometries of the $\mathrm{Fe}_{2}$ coordination sphere (right) for models of the $\left[\mathrm{NiFe}_{2}\right]$ cluster in the neutral and two separate reduced forms, $\mathbf{1}$ (a), $\mathbf{1 a}^{\mathbf{a}^{-}}$(b) and $\mathbf{1} \mathbf{b}^{\mathbf{0}^{-}}$(c).

The most significant spectral feature in the experimental IR spectrum of $\mathbf{1 b}^{\mathbf{b}^{-\boldsymbol{}}}$ in $\mathrm{CH}_{3} \mathrm{CN}$ solution is the presence of a single infrared band at $1714 \mathrm{~cm}^{-1}$ (Figure 3(a), Figure 6(c) and Table 1) which is absent from the spectra of $\mathbf{1}$ and $\mathbf{1 a}^{--}$. DFT calculations of $\mathbf{1}$ and $\mathbf{1 a}^{\cdot-}$ show semi-bridging CO stretches at 1867 and $1891 \mathrm{~cm}^{-1}$, and at 1757 and $1805 \mathrm{~cm}^{-1}$, respectively. These bands reflect a potential overestimation of CO bridging character in $\mathbf{1}$, but match the broad experimental peak seen at $1779 \mathrm{~cm}^{-1}$ for $\mathbf{1 a}^{--}$in $\mathrm{CH}_{3} \mathrm{CN}$ solution. The calculated spectrum of $\mathbf{1 b}^{\mathbf{0}^{-}}$shows a single intense infrared peak in the carbonyl bridging region at $1702 \mathrm{~cm}^{-1}$ (Figure 6(c), Table 1). Thus, the presence of a single low-energy intense infrared band in the experimental and calculated IR spectra of $\mathbf{1 \mathbf { b } ^ { - - }}$ and the qualitative match between the calculated and experimental infrared bands for $\mathbf{1}$ and $\mathbf{1 a}^{\mathbf{*}}$, together with the similarities between the calculated structure for $\mathbf{1}$ and the experimentally determined structure, support the assignment of the $\mathbf{1 \mathbf { b } ^ { \mathbf { } }}$ calculated structure as a model of the second one-electron reduction product of $\mathbf{1}$. 


\section{Photoinduced electron transfer between $\mathrm{NEt}_{3},\left[\mathrm{Ru}(\mathrm{bpy})_{3}\right]\left[\mathrm{PF}_{6}\right]_{2}$ and 1 in $\mathrm{CH}_{3} \mathrm{CN}$}

TRIR and FTIR spectroscopies: $\left[\mathrm{Ru}(\mathrm{bpy})_{3}\right]^{2+}$ has been used extensively as a photosensitiser for photoinduced $\mathrm{H}_{2}$ production and chemical reactions. ${ }^{2 \mathrm{~d}, 41}$ Although $\left[\mathrm{Ru}(\mathrm{bpy})_{3}\right]^{2+}$ does not possess a convenient IR probe [e.g. $v(\mathrm{CO})$ bands], electron transfer to $\mathbf{1}$ can be monitored in the $v(\mathrm{CO})$ region of the IR spectrum via the growth of $\mathbf{1 a}^{\mathbf{a}^{-}}$. The FTIR spectrum of $1(1 \mathrm{mM})$ and $\left[\mathrm{Ru}(\mathrm{bpy})_{3}\right]\left[\mathrm{PF}_{6}\right]_{2}(1 \mathrm{mM})$ in a solution of $\mathrm{CH}_{3} \mathrm{CN}$ and $\mathrm{NEt}_{3}(1.5$ M) possesses three bands originating from 1 [Figure S3(a)]. At 1.5 ns following excitation of the sample, there is no significant change in the $v(\mathrm{CO})$ bands of $\mathbf{1}$ in the TRIR spectrum [Figure S3(b)]. Over the subsequent $500 \mathrm{~ns}$, the parent peaks of $\mathbf{1}$ are observed to deplete as new bands grow in that are associated with the formation of $1 \mathbf{a}^{\mathbf{0}^{-}}$[Figure S3(c)]. Single point kinetic traces recorded for $\mathbf{1}$ and $\mathbf{1 a}^{--}$at 1955 and $1926 \mathrm{~cm}^{-1}$, respectively, [Figure S3(e)] show a sigmoidal growth and decay that are similar to that recorded in the experiments described above using $\left[\operatorname{ReCl}(\mathrm{CO})_{3}(\right.$ bpy) $]$ as the photosensitiser (Figure 2). This suggests that the mechanism of reduction is comparable to that of Scheme 1 and proceeds via the reductive quenching of $*\left[\operatorname{Ru}(\mathrm{bpy})_{3}\right]^{2+}$ to form $\left[\mathrm{Ru}(\mathrm{bpy})_{3}\right]^{+}$. The formation of $\mathbf{1 a}^{\mathbf{0}^{-}}$occurs on a timescale comparable to that of $\left[\operatorname{ReCl}(\mathrm{CO})_{3}(\right.$ bpy) $]$, up to 500 ns [Figure 2 and Figure S3(e)] suggesting that $k_{\text {inter }}$ is comparable in each case. 
$\mathbf{H}_{2}$ production: Our TRIR, photochemical, chemical and electrochemical studies clearly identify the species involved in the photochemical generation of $\mathbf{1 a}^{\mathbf{}^{-}}$and $\mathbf{1 b}^{\mathbf{b}^{-}}$from $\mathbf{1}$ using $\left[\operatorname{ReCl}(\mathrm{CO})_{3}(\mathrm{bpy})\right]$ as a photosensitiser and $\mathrm{NEt}_{3}$ as a sacrificial electron donor. In order to investigate the photochemical production of $\mathrm{H}_{2}$, we used a mixture of TEOA (1 M) and $[\mathrm{HTEOA}]\left[\mathrm{BF}_{4}\right](0.1 \mathrm{M})$ as a combined sacrificial electron donor and proton source in place of $\mathrm{NEt}_{3} . \mathrm{H}_{2}$ production was monitored during the continuous irradiation of $1(0.05 \mathrm{mM}),\left[\operatorname{ReCl}(\mathrm{CO})_{3}(\mathrm{bpy})\right](0.25 \mathrm{mM}), \operatorname{TEOA}(1 \mathrm{M})$ and $[\mathrm{HTEOA}]\left[\mathrm{BF}_{4}\right](0.1 \mathrm{M})$ in degassed $\mathrm{CH}_{3} \mathrm{CN}$, [Figure 7(a)]. After an initial induction period (ca. $5 \mathrm{~min}$ ), the rate of $\mathrm{H}_{2}$ production is linear over ca. $22 \min \left(13.0 \mu\right.$ moles $\mathrm{h}^{-1}$, TOF $\left.=52 \mathrm{~h}^{-1}\right)$, before $\mathrm{H}_{2}$ production decreases to reach a plateau after $c a .3 \mathrm{~h}(13.8 \mu$ moles, TON $=55$, Figure $7(\mathrm{a})$, red dots). The removal of the proton source, $[\mathrm{HTEOA}]\left[\mathrm{BF}_{4}\right]$, from the reaction mixture results in an almost complete loss in activity reaching a plateau after ca. 50 min $[0.8$ $\mu$ moles, TON $=3$, Figure 7(a), black squares], the removal of 1 results in the evolution of only trace amounts of $\mathrm{H}_{2}$ [Figure $\mathrm{S} 9$, green squares], and no $\mathrm{H}_{2}$ could be detected on removal of either TEOA, $\left[\operatorname{ReCl}(\mathrm{CO})_{3}(\mathrm{bpy})\right]$ or the irradiation source. ${ }^{42}$

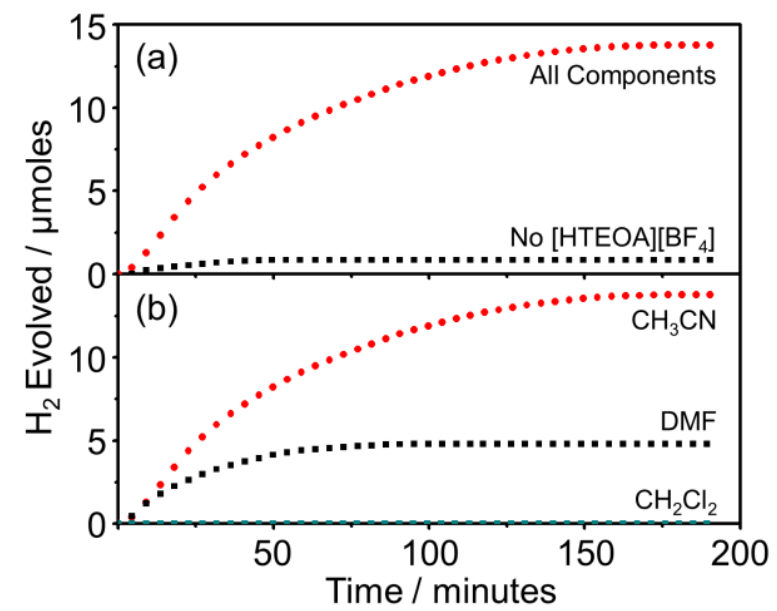

Fig. 7. (a) Time dependent photoinduced $\mathrm{H}_{2}$ evolution from a $5 \mathrm{~mL}$ degassed solution containing $1(0.05 \mathrm{mM}),\left[\operatorname{ReCl}(\mathrm{CO})_{3}(\mathrm{bpy})\right](0.25 \mathrm{mM})$, TEOA $(1 \mathrm{M})$ and $\left.[\mathrm{HTEOA}] \mathrm{BF}_{4}\right]$ $(0.1 \mathrm{M})$ in $\mathrm{CH}_{3} \mathrm{CN}$ at $293 \mathrm{~K}$ (red dots). Control experiment in the absence of [HTEOA] $\left.\mathrm{BF}_{4}\right]$ from the reaction mixture (black squares). (b) Time dependent photoinduced $\mathrm{H}_{2}$ evolution 
carried out at the same concentration as in (a) in $\mathrm{CH}_{3} \mathrm{CN}$ (red dots), DMF (black squares) and $\mathrm{CH}_{2} \mathrm{Cl}_{2}$ (green squares) solutions. Irradiation was performed using a Xe lamp (250 W) and a $\lambda<420 \mathrm{~nm}$ cut-off filter.

$\mathrm{H}_{2}$ production was observed in $\mathrm{CH}_{3} \mathrm{CN}$ and DMF. However, in $\mathrm{CH}_{2} \mathrm{Cl}_{2}$ no $\mathrm{H}_{2}$ evolution was detected [Figure 7(b) and Figure S10]. In DMF, $\mathrm{H}_{2}$ evolution ceased after $1.5 \mathrm{~h}$ with a total of $4.8 \mu$ moles detected $(\mathrm{TON}=19)$. The removal of $[\mathrm{HTEOA}]\left[\mathrm{BF}_{4}\right]$ or $\mathbf{1}$ from mixtures in DMF leads to solutions that can generate $\mathrm{H}_{2}$, producing after 45 min 2.4 and $1.2 \mu$ moles of $\mathrm{H}_{2}$, respectively $(\mathrm{TON}=10$ and 5, respectively, Figure S11). Thus, it appears that in DMF solution $\left[\mathrm{ReCl}(\mathrm{CO})_{3}(\mathrm{bpy})\right]$ can photochemically catalyse the production of $\mathrm{H}_{2}$ with a lower TON relative to 1 . No $\mathrm{H}_{2}$ evolution was detected in any experiment performed in $\mathrm{CH}_{2} \mathrm{Cl}_{2}$ solution. Thus, back-electron transfer from $\mathbf{1 a}^{\cdot-}$ to the electron donor rather than being available for catalysis may be occurring in $\mathrm{CH}_{2} \mathrm{Cl}_{2}$ solution, consistent with the FTIR spectroscopic results [Figure 3(c)] for reactions carried out in $\mathrm{CH}_{2} \mathrm{Cl}_{2}$ solution. Although photocatalysis is only observed in solutions that form $\mathbf{1 b}^{\mathbf{*}}\left(\mathrm{CH}_{3} \mathrm{CN}\right.$ and DMF), we were unable to determine the more catalytically active species from these $\mathrm{H}_{2}$ production experiments.

The rate of $\mathrm{H}_{2}$ production was also investigated using $\left[\mathrm{Ru}(\mathrm{bpy})_{3}\right]\left[\mathrm{PF}_{6}\right]_{2}$ as the photosensitiser [Figure S12] in $\mathrm{CH}_{3} \mathrm{CN}$. Mixtures containing $\left[\mathrm{Ru}(\mathrm{bpy})_{3}\right]\left[\mathrm{PF}_{6}\right]_{2}$ demonstrate slower rates of $\mathrm{H}_{2}$ production compared to $\left[\mathrm{ReCl}(\mathrm{CO})_{3}(\mathrm{bpy})\right]$, TOF $=23 \mathrm{~h}^{-1}$ over $c a .17 \mathrm{~min}$ using $\left[\mathrm{Ru}(\mathrm{bpy})_{3}\right]\left[\mathrm{PF}_{6}\right]_{2}, \mathrm{TOF}=52 \mathrm{~h}^{-1}$ over ca. 22 min using $\left[\operatorname{ReCl}(\mathrm{CO})_{3}(\mathrm{bpy})\right]$. In total, $\left[\mathrm{Ru}(\mathrm{bpy})_{3}\right]\left[\mathrm{PF}_{6}\right]_{2}$ produces $3.6 \mu$ moles of $\mathrm{H}_{2}(\mathrm{TON}=14)$ over $1.5 \mathrm{~h}$ of photolysis whereas $\left[\mathrm{ReCl}(\mathrm{CO})_{3}(\mathrm{bpy})\right]$ was able to sustain $\mathrm{H}_{2}$ evolution for ca. $3 \mathrm{~h}$ producing $13.8 \mu$ moles of $\mathrm{H}_{2}$ $(\mathrm{TON}=55)$ before cessation. No $\mathrm{H}_{2}$ could be detected on removal of either TEOA, $\left[\mathrm{Ru}(\mathrm{bpy})_{3}\right]\left[\mathrm{PF}_{6}\right]_{2}$ or the irradiation source. The control experiment in which $[\mathrm{HTEOA}]\left[\mathrm{BF}_{4}\right]$ was not added produced a similar total amount of $\mathrm{H}_{2}(2.2 \mu$ moles, TON $=9)$ when compared 
to the complete component system, and when $\mathbf{1}$ was not added the total amount of $\mathrm{H}_{2}$ detected was $0.7 \mu$ moles $(\mathrm{TON}=3$ ) (Figure $\mathrm{S} 12)$. For both control experiments, a fine black precipitate was observed after photolysis. It appears that the decomposition of $\left[\mathrm{Ru}(\mathrm{bpy})_{3}\right]\left[\mathrm{PF}_{6}\right]_{2}$ to produce small amounts of $\mathrm{H}_{2}$ seems to dominate $\mathrm{H}_{2}$ production in these systems. This contrasts with the use of $\left[\operatorname{ReCl}(\mathrm{CO})_{3}(\mathrm{bpy})\right]$ as the photosensitiser, where a large difference between the complete component system and the controls was observed [Figure 7(a)]. This, together with the lower rate of $\mathrm{H}_{2}$ production and lower total volumes of $\mathrm{H}_{2}$ evolved indicates that $\left[\mathrm{ReCl}(\mathrm{CO})_{3}(\mathrm{bpy})\right]$ is more suited as a photosensitiser than $\left[\mathrm{Ru}(\mathrm{bpy})_{3}\right]\left[\mathrm{PF}_{6}\right]_{2}$ in the photochemical production of $\mathrm{H}_{2}$ catalysed by $\mathbf{1}$. This is consistent with published results comparing $\left[\operatorname{ReBr}(\mathrm{CO})_{3}(\right.$ bpy) $]$ and $\left[\mathrm{Ru}(\text { bpy })_{3}\right]\left[\mathrm{PF}_{6}\right]_{2}$ as chromophores for a hydrogen evolving catalyst in $\mathrm{DMF}$ in which $\left[\operatorname{ReBr}(\mathrm{CO})_{3}(\right.$ bpy) $]$ was able to sustain catalytic activity from a cobalt containing catalyst for longer than $\left[\mathrm{Ru}(\mathrm{bpy})_{3}\right]\left[\mathrm{PF}_{6}\right]_{2}$, producing over double the amount of $\mathrm{H}_{2}$ after $9 \mathrm{~h}$ or irradiation. ${ }^{43}$

\section{Conclusions}

We have confirmed that the $\left[\mathrm{NiFe}_{2}\right]$ complex, 1 , can be reduced to its catalytically competent anion form using $\left[\mathrm{ReCl}(\mathrm{CO})_{3}(\mathrm{bpy})\right]$ or $\left[\mathrm{Ru}(\mathrm{bpy})_{3}\right]\left[\mathrm{PF}_{6}\right]_{2}$ as photosensitisers in the presence of a sacrificial electron donor, $\mathrm{NEt}_{3}$ or TEOA. Time-resolved infrared spectroscopy has probed the intermediates throughout the photochemical reduction of 1 (Figure 8). Once reduced, FTIR spectroscopy has proved a valuable method in studying the fate of $\mathbf{1 a}^{\cdot-}$. Two

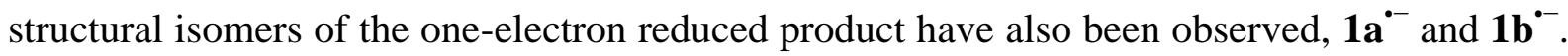
Density functional theory supports this observation revealing that $\mathbf{1}$ and $\mathbf{1 a}^{\mathbf{0}^{-}}$are structurally similar with each cluster possessing all terminal CO groups. In contrast $\mathbf{1 b}^{\mathbf{b}^{-}}$possesses two fully bridging carbonyl ligands. In a system containing a combination of $\mathbf{1}$, $\left[\mathrm{ReCl}(\mathrm{CO})_{3}(\mathrm{bpy})\right]$, TEOA and $[\mathrm{HTEOA}]\left[\mathrm{BF}_{4}\right]$ in $\mathrm{CH}_{3} \mathrm{CN}$ a maximum turn-over number of 
55 has been achieved based on 1 with a maximum turn-over frequency of $52 \mathrm{~h}^{-1}$ over the first ca. $0.4 \mathrm{~h}$ of photolysis. This represents the first example of light-driven $\mathrm{H}_{2}$ production involving a low molecular weight analogue of the active site of the [NiFe] hydrogenase. However, we were not able to determine whether $\mathbf{1 a}^{\mathbf{a}^{-}}$or $\mathbf{1 \mathbf { b } ^ { \mathbf { } ^ { - } }}$ is responsible for the observed catalytic activity. In $\mathrm{CH}_{3} \mathrm{CN}$ and $\mathrm{DMF}$ the formation of $\mathbf{1 a}^{\mathbf{0}}$ is followed by the thermal conversion to $\mathbf{1 b}^{--}$. In $\mathrm{CH}_{2} \mathrm{Cl}_{2}$ the thermal formation of $\mathbf{1 b}^{-\boldsymbol{*}}$ is not observed after the formation of $\mathbf{1 a}^{\mathbf{0}}$. Instead the parent complex $\mathbf{1}$ is reformed whilst $\mathbf{1 a}^{\mathbf{0}^{-}}$is lost from the solution. Studies are currently in progress to optimise reaction conditions and to develop further new generations of catalysts to increase the efficiency of $\mathrm{H}_{2}$ production.

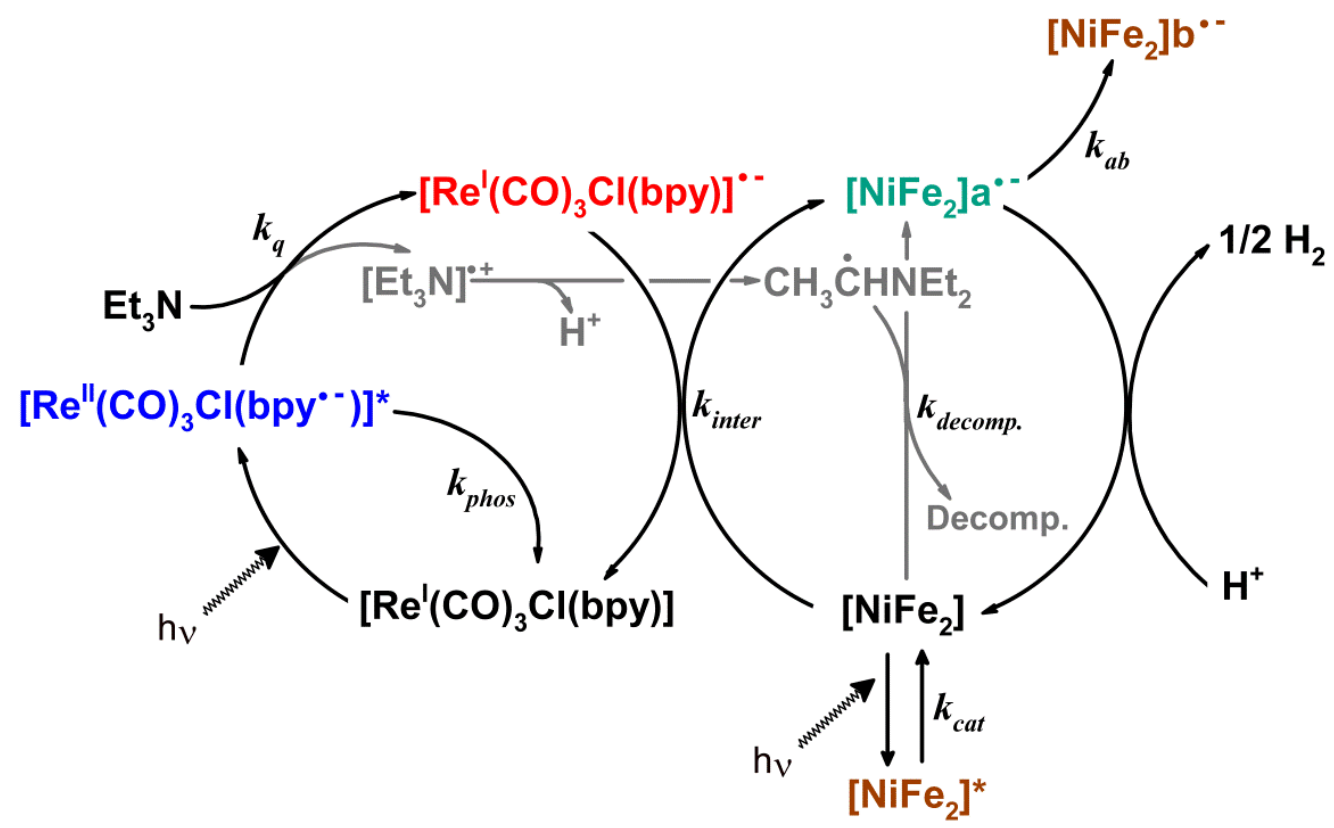

Fig. 8. Proposed schematic and rate constants for the dominant pathways involved in photochemical reduction of $\mathbf{1}\left(\left[\mathrm{NiFe}_{2}\right]\right)$ by $\left[\mathrm{Re}(\mathrm{CO})_{3} \mathrm{Cl}(\mathrm{bpy})\right]$, including the decomposition of the electron donor $\left(\mathrm{NEt}_{3}\right)$ and the formation of $\mathbf{1 b}^{\mathbf{}^{-}}\left(\left[\mathrm{NiFe}_{2}\right] \mathrm{b}^{\mathbf{}^{-}}\right)$. These mechanisms are proposed from TRIR, FTIR and hydrogen evolution experiments in $\mathrm{CH}_{3} \mathrm{CN}$. $k_{\text {cat }}=c a .1 \mathrm{x}$ $10^{10} \mathrm{~s}^{-1} ; k_{\text {phos }}=3.3 \times 10^{7} \mathrm{~s}^{-1} ;^{44} k_{\mathrm{q}}=8 \times 10^{7} \mathrm{M}^{-1} \mathrm{~s}^{-1}$ (for TEOA) ${ }^{45} k_{\text {inter }}=6.7 \times 10^{9} \mathrm{M}^{-1} \mathrm{~s}^{-1}$; $k_{\text {decomp. }}=c a .6 .7 \times 10^{9} \mathrm{M}^{-1} \mathrm{~s}^{-1}$ similar rate to $k_{\text {inter }} ; k_{\mathrm{ab}}=19.4( \pm 0.2) \times 10^{-4} \mathrm{~s}^{-1}\left(\mathrm{in} \mathrm{CH}_{3} \mathrm{CN}\right)$, $1.57( \pm 0.02) \times 10^{-4} \mathrm{~s}^{-1}$ (in DMF). Rate constants were measured in the absence of any proton source (see text) and it was not possible to confirm whether $\mathbf{1 a}^{\mathbf{*}}$ or $\mathbf{1 b}^{\mathbf{*}}$ was the source of catalytic activity in these experiments. 


\section{Supporting information}

Additional data relating to TRIR, electrochemical, DFT and $\mathrm{H}_{2}$ production experiments are available in the supplementary information. This information is available free of charge via the internet at http://pubs.acs.org/.

\section{Acknowledgements}

We thank the EPSRC and the University of Nottingham for support. MS acknowledges receipt of an ERC Advanced Grant and MWG a Royal Society Wolfson Merit Award.

\section{References}

(1) Service, R. F. Science 2005, 309, 548-551.

(2) (a) Eckenhoff, W. T.; Eisenberg, R. Dalton Trans. 2012, 41, 13004-13021; (b) Melis, A.; Melnicki, M. R. Int. J. Hydrogen Energy 2006, 31, 1563-1573; (c) Cracknell, J. A.; Vincent, K. A.; Armstrong, F. A. Chem. Rev. 2008, 108, 2439-2461; (d) Young, K. J.; Martini, L. A.; Milot, R. L.; Snoeberger, R. C., III; Batista, V. S.; Schmuttenmaer, C. A.; Crabtree, R. H.; Brudvig, G. W. Coord. Chem. Rev. 2012, 256, 2503-2520.

(3) (a) Bard, A. J.; Fox, M. A. Acc. Chem. Res. 1995, 28, 141-145; (b) Wang, M.; Na, Y.; Gorlov, M.; Sun, L. C. Dalton Trans. 2009, 6458-6467.

(4) Esswein, M. J.; Nocera, D. G. Chem. Rev. 2007, 107, 4022-4047.

(5) (a) Volbeda, A.; Charon, M. H.; Piras, C.; Hatchikian, E. C.; Frey, M.; Fontecillacamps, J. C. Nature 1995, 373, 580-587; (b) Peters, J. W.; Lanzilotta, W. N.; Lemon, B. J.; Seefeldt, L. C. Science 1998, 282, 1853-1858; (c) Nicolet, Y.; Piras, C.; Legrand, P.; Hatchikian, C. E.; Fontecilla-Camps, J. C. Struct. Fold. \& Des. 1999, 7, 13-23.

(6) Bouwman, E.; Reedijk, J. Coord. Chem. Rev. 2005, 249, 1555-1581.

(7) (a) Tard, C.; Pickett, C. J. Chem. Rev. 2009, 109, 2245-2274; (b) Liu, X. M.; Ibrahim, S. K.; Tard, C.; Pickett, C. J. Coord. Chem. Rev. 2005, 249, 1641-1652; (c) Felton, G. A. N.; Mebi, C. A.; Petro, B. J.; Vannucci, A. K.; Evans, D. H.; Glass, R. S.; Lichtenberger, D. L. J. Organomet. Chem. 2009, 694, 2681-2699; (d) Evans, D. J.; Pickett, C. J. Chem. Soc. Rev. 2003, 32, 268-275.

(8) (a) Darensbourg, M. Y.; Lyon, E. J.; Smee, J. J. Coord. Chem. Rev. 2000, 206, 533-561; (b) Marr, A. C.; Spencer, D. J. E.; Schröder, M. Coord. Chem. Rev. 2001, 219, 1055-1074; (c) Dawson, J.; Ghiotto, F.; McMaster, J.; Schröder, M. in Molecular Solar Fuels, Ed. Wydrzynski, T.; Hillier, W. Book Series: ENERGY Vol 12, 326-386, RSC, Cambridge UK, 2011; (d) Zhu, W. F.; Marr, A. C.; Wang, Q.; Neese, F.; Spencer, D. J. E.; Blake, A. J.; Cooke, P. A.; Wilson, C.; Schröder, M. Proc. Natl. Acad. Sci. U. S. A. 2005, 102, 18280-18285; (e) Stenson, P. A.; Marin-Becerra, A.; Wilson, C.; 
Blake, A. J.; McMaster, J.; Schröder, M. Chem. Commun. 2006, 317-319; (f) van Gastel, M.; Shaw, J. L.; Blake, A. J.; Flores, M.; Schröder, M.; McMaster, J.; Lubitz, W. Inorg. Chem. 2008, 47, 1168811697; (g) Perra, A.; Wang, Q.; Blake, A. J.; Davies, E. S.; McMaster, J.; Wilson, C.; Schröder, M. Dalton Trans. 2009, 925-931.

(9) Frey, M. ChemBioChem 2002, 3, 153-160.

(10) Wang, Q.; Barclay, J. E.; Blake, A. J.; Davies, E. S.; Evans, D. J.; Marr, A. C.; McInnes, E. J. L.; McMaster, J.; Wilson, C.; Schröder, M. Chem. Eur. J. 2004, 10, 3384-3396.

(11) Perra, A.; Davies, E. S.; Hyde, J. R.; Wang, Q.; McMaster, J.; Schröder, M. Chem. Commun. 2006, 1103-1105.

(12) (a) Mejia-Rodriguez, R.; Chong, D. S.; Reibenspies, J. H.; Soriaga, M. P.; Darensbourg, M. Y. J. Am. Chem. Soc. 2004, 126, 12004-12014; (b) Chong, D. S.; Georgakaki, I. P.; Mejia-Rodriguez, R.; Samabria-Chinchilla, J.; Soriaga, M. P.; Darensbourg, M. Y. Dalton Trans. 2003, 4158-4163.

(13) Na, Y.; Pan, J. X.; Wang, M.; Sun, L. C. Inorg. Chem. 2007, 46, 3813-3815.

(14) Na, Y.; Wang, M.; Pan, J. X.; Zhang, P.; Åkermark, B.; Sun, L. C. Inorg. Chem. 2008, 47, 2805-2810.

(15) Zhang, P.; Wang, M.; Na, Y.; Li, X. Q.; Jiang, Y.; Sun, L. C. Dalton Trans. 2010, 39, 12041206.

(16) Streich, D.; Astuti, Y.; Orlandi, M.; Schwartz, L.; Lomoth, R.; Hammarström, L.; Ott, S. Chem. Eur. J. 2010, 16, 60-63.

(17) Wang, F.; Wang, W. G.; Wang, X. J.; Wang, H. Y.; Tung, C. H.; Wu, L. Z. Angew. Chem., Int. Ed. 2011, 50, 3193-3197.

(18) Wang, H. Y.; Wang, W. G.; Si, G.; Wang, F.; Tung, C. H.; Wu, L. Z. Langmuir 2010, 26, 9766-9771.

(19) (a) McLaughlin, M. P.; McCormick, T. M.; Eisenberg, R.; Holland, P. L. Chem. Commun. 2011, 47, 7989-7991; (b) Helm, M. L.; Stewart, M. P.; Bullock, R. M.; DuBois, M. R.; DuBois, D. L. Science 2011, 333, 863-866; (c) Han, Z. J.; McNamara, W. R.; Eum, M. S.; Holland, P. L.; Eisenberg, R. Angew. Chem., Int. Ed. 2012, 51, 1667-1670.

(20) Han, Z.; Qiu, F.; Eisenberg, R.; Holland, P. L.; Krauss, T. D. Science 2012, 338, 1321-1324.

(21) Wrighton, M.; Morse, D. L. J. Am. Chem. Soc. 1974, 96, 998-1003.

(22) Braddock, J. N.; Meyer, T. J. J. Am. Chem. Soc. 1973, 95, 3158-3162.

(23) Ono, H.; Seki, R.; Ikeda, R.; Ishida, H. J. Mol. Struct. 1995, 345, 235-243.

(24) Brennan, P.; George, M. W.; Jina, O. S.; Long, C.; McKenna, J.; Pryce, M. T.; Sun, X. Z.; Vuong, K. Q. Organometallics 2008, 27, 3671-3680.

(25) Shao, Y.; Molnar, L. F.; Jung, Y.; Kussmann, J.; Ochsenfeld, C.; Brown, S. T.; Gilbert, A. T. B.; Slipchenko, L. V.; Levchenko, S. V.; O'Neill, D. P.; DiStasio, R. A., Jr.; Lochan, R. C.; Wang, T.; Beran, G. J. O.; Besley, N. A.; Herbert, J. M.; Lin, C. Y.; Van Voorhis, T.; Chien, S. H.; Sodt, A.; Steele, R. P.; Rassolov, V. A.; Maslen, P. E.; Korambath, P. P.; Adamson, R. D.; Austin, B.; Baker, 
J.; Byrd, E. F. C.; Dachsel, H.; Doerksen, R. J.; Dreuw, A.; Dunietz, B. D.; Dutoi, A. D.; Furlani, T. R.; Gwaltney, S. R.; Heyden, A.; Hirata, S.; Hsu, C.-P.; Kedziora, G.; Khalliulin, R. Z.; Klunzinger, P.; Lee, A. M.; Lee, M. S.; Liang, W.; Lotan, I.; Nair, N.; Peters, B.; Proynov, E. I.; Pieniazek, P. A.; Rhee, Y. M.; Ritchie, J.; Rosta, E.; Sherrill, C. D.; Simmonett, A. C.; Subotnik, J. E.; Woodcock, H. L., III; Zhang, W.; Bell, A. T.; Chakraborty, A. K.; Chipman, D. M.; Keil, F. J.; Warshel, A.; Hehre, W. J.; Schaefer, H. F., III; Kong, J.; Krylov, A. I.; Gill, P. M. W.; Head-Gordon, M. Phys. Chem. Chem. Phys. 2006, 8, 3172-3191.

(26) Adamo, C.; Barone, V. J. Chem. Phys. 1999, 110, 6158-6170.

(27) Dolg, M.; Wedig, U.; Stoll, H.; Preuss, H. J. Chem. Phys. 1987, 86, 866-872.

(28) Krishnan, R.; Binkley, J. S.; Seeger, R.; Pople, J. A. J. Chem. Phys. 1980, 72, 650-654.

(29) Gill, P. M. W.; Johnson, B. G.; Pople, J. A. Chem. Phys. Lett. 1993, 209, 506-512.

(30) (a) Merrick, J. P.; Moran, D.; Radom, L. J. Phys. Chem. A 2007, 111, 11683-11700; (b) Scott, A. P.; Radom, L. J. Phys. Chem. 1996, 100, 16502-16513.

(31) Greetham, G. M.; Burgos, P.; Cao, Q.; Clark, I. P.; Codd, P. S.; Farrow, R. C.; George, M. W.; Kogimtzis, M.; Matousek, P.; Parker, A. W.; Pollard, M. R.; Robinson, D. A.; Xin, Z.-J.; Towrie, M. Appl. Spectrosc. 2010, 64, 1311-1319.

(32) Lomont, J. P.; Shearer, A. J.; Nguyen, S. C.; Harris, C. B. Organometallics 2013, 32, 21782186.

(33) (a) Bhasikuttan, A. C.; Suzuki, M.; Nakashima, S.; Okada, T. J. Am. Chem. Soc. 2002, 124, 8398-8405; (b) Glyn, P.; George, M. W.; Hodges, P. M.; Turner, J. J. J. Chem. Soc., Chem. Commun. 1989, 1655-1657; (c) Butler, J. M.; George, M. W.; Schoonover, J. R.; Dattelbaum, D. M.; Meyer, T. J. Coord. Chem. Rev. 2007, 251, 492-514.

(34) George, M. W.; Johnson, F. P. A.; Westwell, J. R.; Hodges, P. M.; Turner, J. J. J. Chem. Soc., Dalton Trans. 1993, 2977-2979.

(35) Delaive, P. J.; Foreman, T. K.; Giannotti, C.; Whitten, D. G. J. Am. Chem. Soc. 1980, 102, $5627-5631$.

(36) Probst, B.; Rodenberg, A.; Guttentag, M.; Hamm, P.; Alberto, R. Inorg. Chem. 2010, 49, 6453-6460.

(37) Cohen, S. G.; Parola, A.; Parsons, G. H. Chem. Rev. 1973, 73, 141-161.

(38) (a) Chan, S. F.; Chou, M.; Creutz, C.; Matsubara, T.; Sutin, N. J. Am. Chem. Soc. 1981, 103, 369-379; (b) Neshvad, G.; Hoffman, M. Z. J. Phys. Chem. 1989, 93, 2445-2452; (c) Kalyanasundaram, K. J. Chem. Soc., Faraday Trans. 2 1986, 82, 2401-2415.

(39) (a) Kutal, C.; Weber, M. A.; Ferraudi, G.; Geiger, D. Organometallics 1985, 4, 2161-2166; (b) Kutal, C.; Corbin, A. J.; Ferraudi, G. Organometallics 1987, 6, 553-557.

(40) (a) de Carcer, I. A.; DiPasquale, A.; Rheingold, A. L.; Heinekey, D. M. Inorg. Chem. 2006, 45, 8000-8002; (b) Borg, S. J.; Behrsing, T.; Best, S. P.; Razavet, M.; Liu, X. M.; Pickett, C. J. J. Am. Chem. Soc. 2004, 126, 16988-16999. 
(41) Narayanam, J. M. R.; Stephenson, C. R. J. Chem. Soc. Rev. 2011, 40, 102-113.

(42) It should be noted that when the control experiment in the absence of $\mathbf{1}$ was prepared using standard Schlenck techniques rather than in a glove box, $c a .3 \mu$ moles of $\mathrm{H}_{2}$ were detected after $3 \mathrm{~h}$ irradiation.

(43) Probst, B.; Kolano, C.; Hamm, P.; Alberto, R. Inorg. Chem. 2009, 48, 1836-1843.

(44) Hayashi, Y.; Kita, S.; Brunschwig, B. S.; Fujita, E. J. Am. Chem. Soc. 2003, 125, 1197611987.

(45) Takeda, H.; Koike, K.; Inoue, H.; Ishitani, O. J. Am. Chem. Soc. 2008, 130, 2023-2031. 


\section{For Table of Contents Only}

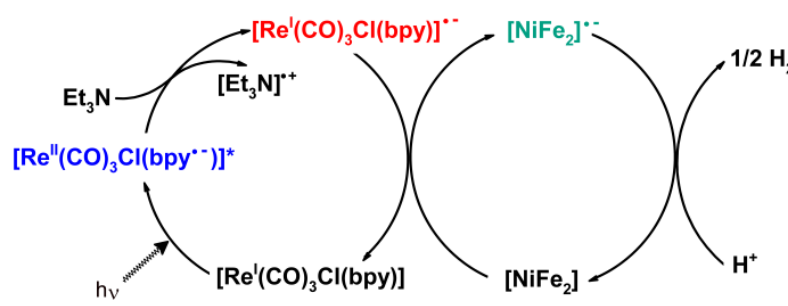

Light-driven electron transfer to $\left[\mathrm{NiFe}_{2}\right]$

$\left(\left[\mathrm{Ni}(\mathrm{L}) \mathrm{Fe}_{2}(\mathrm{CO})_{6}\right], \mathrm{L}^{2-}=\left(\mathrm{CH}_{3} \mathrm{C}_{6} \mathrm{H}_{3} \mathrm{~S}_{2}\right)_{2}\left(\mathrm{CH}_{2}\right)_{3}\right)$ using $\left[\operatorname{ReCl}(\mathrm{CO})_{3}(\right.$ bpy $\left.)\right]$ as a photosensitiser and $\mathrm{NEt}_{3}$ as a sacrificial electron donor forms the basis of photocatalytic $\mathrm{H}_{2}$ production using a low molecular weight $[\mathrm{NiFe}]$ hydrogenase mimic. 